\title{
Sediment budget monitoring of debris-flow and bedload transport in the Manival Torrent, SE France
}

\author{
J. I. Theule ${ }^{1}$, F. Liébault ${ }^{1}$, A. Loye ${ }^{2}$, D. Laigle ${ }^{1}$, and M. Jaboyedoff ${ }^{2}$ \\ ${ }^{1}$ Irstea Grenoble, Unité de Recherche ETNA (Erosion Torrentielle, Neige et Avalanches), Saint-Martin-d'Hères, France \\ ${ }^{2}$ Université de Lausanne, Faculté des Géosciences et de l'Environnement, IGAR (Institut de Géomatique et \\ d'Analyse du Risque), Lausanne, Switzerland \\ Correspondence to: F. Liébault (frederic.liebault@irstea.fr)
}

Received: 20 September 2011 - Revised: 20 January 2012 - Accepted: 31 January 2012 - Published: 23 March 2012

\begin{abstract}
Steep mountain catchments typically experience large sediment pulses from hillslopes which are stored in headwater channels and remobilized by debris-flows or bedload transport. Event-based sediment budget monitoring in the active Manival debris-flow torrent in the French Alps during a two-year period gave insights into the catchment-scale sediment routing during moderate rainfall intensities which occur several times each year. The monitoring was based on intensive topographic resurveys of low- and high-order channels using different techniques (cross-section surveys with total station and high-resolution channel surveys with terrestrial and airborne laser scanning). Data on sediment output volumes from the main channel were obtained by a sediment trap. Two debris-flows were observed, as well as several bedload transport flow events. Sediment budget analysis of the two debris-flows revealed that most of the debris-flow volumes were supplied by channel scouring (more than $92 \%$ ). Bedload transport during autumn contributed to the sediment recharge of high-order channels by the deposition of large gravel wedges. This process is recognized as being fundamental for debris-flow occurrence during the subsequent spring and summer. A time shift of scour-and-fill sequences was observed between low- and high-order channels, revealing the discontinuous sediment transfer in the catchment during common flow events. A conceptual model of sediment routing for different event magnitude is proposed.
\end{abstract}

\section{Introduction}

Channelized debris-flows are common, natural processes in the French Alps. They typically occur in steep, small to average size mountain streams (torrents) and induce each year disturbances and/or damages to infrastructure. The most striking feature of debris-flows is their ability to transport a considerable volume of sediment over long distances (typically several kilometres) and at a relatively high velocity (generally between 2 to $20 \mathrm{~m} \mathrm{~s}^{-1}$ ). Poorly sorted sediments mixed with water and organic debris form destructive surges depositing on alluvial fans, most of them being urbanized. The prevention of natural hazards related to debris-flows requires a better understanding of sediment transfer in debrisflow catchments.

The volume of channelized debris-flows have frequently been identified as influenced by channel scouring along the flow path (see Hungr et al., 2005 for a recent review). Several case studies of debris-flows triggered by slope failures reported that the volume of initial failures were insignificant as compared to the total volume of the event (Benda and Dunne, 1987; Berger et al., 2011a; Remaître et al., 2005). Debrisflows incorporate in-channel sediment as they move down slope. This is known as debris-flow bulking and the rate at which debris-flows scour the channel is referred as the yield rate (expressed in $\mathrm{m}^{3}$ per unit length of channel). Therefore, the presence of erodible sediment in headwater channels is recognized as a primary control on the timing and magnitude of debris-flows (Jakob et al., 2005). Some authors proposed to discriminate supply- and transport-limited debrisflow catchments as a function of the sediment recharge rate for low-order channels, this being defined as the rate at which colluvium fills the scoured channel after the passage of a debris-flow (Bovis and Jakob, 1999). The higher the recharge rate is, the higher the susceptibility of the catchment to produce a debris-flow during high-intensity rainfall events.

Temporal fluctuations and spatial distributions of channel storage are, therefore, key controls of debris-flow occurrence and magnitude. In steepland catchments, these fluctuations are influenced by both debris-flows and bedload transport, 
but the respective influence of both can be very different between investigated sites. Field studies of sediment transfer in Oregon's steepland catchments revealed that low-order channels accumulate sediment input from hillslopes for thousands of years until a slope failure occurs and transforms into a debris-flow which scours the sediment of first- to second-order channels (Benda, 1990; Benda and Dunne, 1987). Given the nature of coarse sediments delivered to headwaters, common runoff events are unable to mobilize them as bedload and, therefore, sediments are accumulated for very long periods of time. Similar sequences of scourand-fill were reported in other regions, but over much shorter timescales. A recent study of an alluvial fan in New Zealand revealed seasonal cut-and-fill sequences driven by successive wet and dry periods (Fuller and Marden, 2010). In this case, aggradation phases of the fan are related to large sediment influx from debris-flows during wet periods, when failures are triggered in the upper catchment. Degradation phases are related to bedload transport events during autumn. Observations of a first-order channel in Japan showed sediment accumulation during winter freeze-thaw cycles, and channel scouring during summer convective storms (Imaizumi et al., 2006). Most of the sediment flushing was driven by debrisflows while bedload transport was considered as a minor sediment transport process. Annual sediment transfer investigations in the Illgraben catchment (Switzerland) also revealed the importance of alternating scour and fill of the channel in the understanding of sediment transfer in complex debrisflow catchments (Berger et al., 2011a), however, interactions between debris-flow and bedload transport were not emphasized.

Intensive seasonal field observations of the sediment cascade in steepland catchments prone to debris-flows are still lacking in the alpine environment and notably in catchments where sediment transfer is driven by both debris-flow and bedload transport. These two processes may occur during the same flow event, but some events do not produce debrisflows when bed material is entrained only by shear stress exerted from water flow. We refer the latter case as a bedload transport event. This paper presents observations from frequent field surveys of sediment transfer in a debris-flow torrent in the French Alps, where sequences of scour-andfill were studied at a seasonal timescale from first- to fourthorder channels. These observations allowed us to (1) quantify the relative contribution of channel scouring for debrisflow volumes, and to (2) characterise the seasonal cycles of scour-and-fill from low- to high-order channels with respect to the driving processes (debris-flow vs. bedload).
Table 1. General features of the Manival Torrent.

\begin{tabular}{ll}
\hline Drainage area $\left(\mathrm{km}^{2}\right)$ & 3.6 \\
Minimum elevation (m a.s.l.) & 570 \\
Maximum elevation (m a.s.l.) & 1738 \\
Mean catchment slope (\%) & 81 \\
Length of the study reach (km) & 1.8 \\
Mean slope of the study reach (\%) & 16 \\
Mean active channel width (m) & 15 \\
Monitoring period & Jul 2009-Dec 2010 \\
Number of topographic surveys & 9 \\
Number of check-dams along the study reach & 19 \\
\hline
\end{tabular}

\section{Material and methods}

\subsection{Study site}

The Manival is a very active debris-flow torrent near Grenoble in the Chartreuse Mountains of the Northern French Prealps (Fig. 1). It flows intermittently into the Isère River in the Grésivaudan valley. The high frequency of debris-flow events (one every year since 2008), easy access throughout the main channel and presence of a large sediment trap $\left(25000 \mathrm{~m}^{3}\right)$ in the channel (protecting the urbanized alluvial fan against debris-flows) makes the Manival site suitable for implementing a monitoring programme of sediment transfer associated with debris-flows. The $1.8-\mathrm{km}$ study reach extends from the apex of the alluvial fan to the sediment trap.

The $3.6-\mathrm{km}^{2}$ catchment above the sediment trap has $1130 \mathrm{~m}$ of relief with a mean catchment slope of $81 \%$ (Table 1). Bedrock is composed of highly fractured, alternating sequences of Jurassic marls and limestones. A long reverse fault runs through the axis of the catchment with secondary faults found regularly on the head and east side of the catchment. The bedrock is covered by thick colluvial deposits which are mobilized by shallow landslides, hillslope debrisflows and snow avalanches. Limestone rock faces are prone to active rockfall which supplies debris to talus slopes. During the snowmelt season, gullies located below rock faces can experience one rockfall every 5 to $10 \mathrm{~min}$ (according to the authors' field experiences). Detailed descriptions of the geologic structure, including a 3-D geologic diagram of the Manival catchment, are found in Loye et al. (2012).

The mean annual precipitation measured at the nearest meteorological station (Saint-Hilaire-du-Touvet) is $1450 \mathrm{~mm}$. Precipitation consists of intense rainfall from convective storms in spring and summer (May to September) where debris-flows typically occur, steady low-duration rainfall in the autumn (September to December) where bedload transport occurs, and snow in the winter (January to March) when the channel is dormant.

Upstream of the sediment trap, which is located at the distal limit of the upper third of the alluvial fan, the mean channel slope is $16 \%$ over $1.8 \mathrm{~km}$ to the apex of the alluvial fan. This steep-slope channel has a mean active width of $\sim 15 \mathrm{~m}$ 

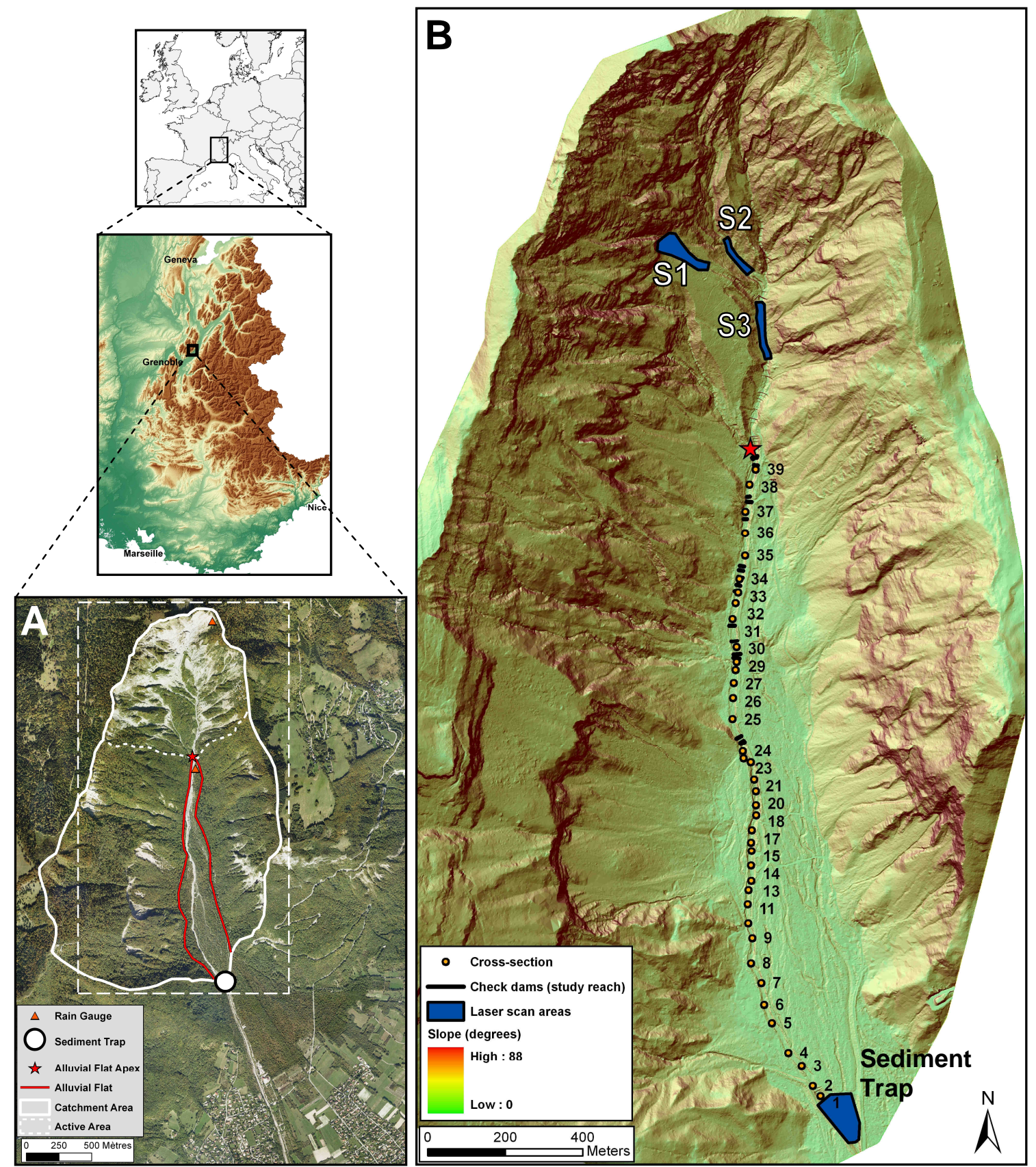

Fig. 1. (A) Orthophoto view of the Manival catchment (image @ Aerodata International Surveys) located at $45^{\circ} 17^{\prime} \mathrm{N}, 5^{\circ} 49.75^{\prime} \mathrm{E} ;(\mathbf{B})$ shaded relief map of the Manival study reach derived from airborne LiDAR surveys, displaying locations of cross-sections, check-dams and laser scanned areas; Sites S1-S3 refer to multi-scanned headwater reaches (Fig. 9).

(range: 10-20 m) and presents a typical morphology of a debris-flow scoured channel with levees, boulder fronts and coarse lags (Fig. 2a). It is entrenched into the wide alluvial fan (40 to 250-m wide, increasing downstream). Macroforms related to bedload transport are observed along the main channel. They can be defined as gravel wedges with well sorted grain-size distributions (Fig. 2b). These macroforms partly or totally fill the debris-flow scoured cross-sections and reveal that bedload transport is an important component of the torrent sediment budget. Further geomorphic descriptions can be found in previous works (Peteuil et al., 2008; Veyrat-Charvillon and Memier, 2006).

Approximately 180 check-dams were constructed since the 1890s throughout the main channel and small gullies. They are managed by the French forest and torrent-control service of the Isère Department (ONF-RTM38). Nineteen 

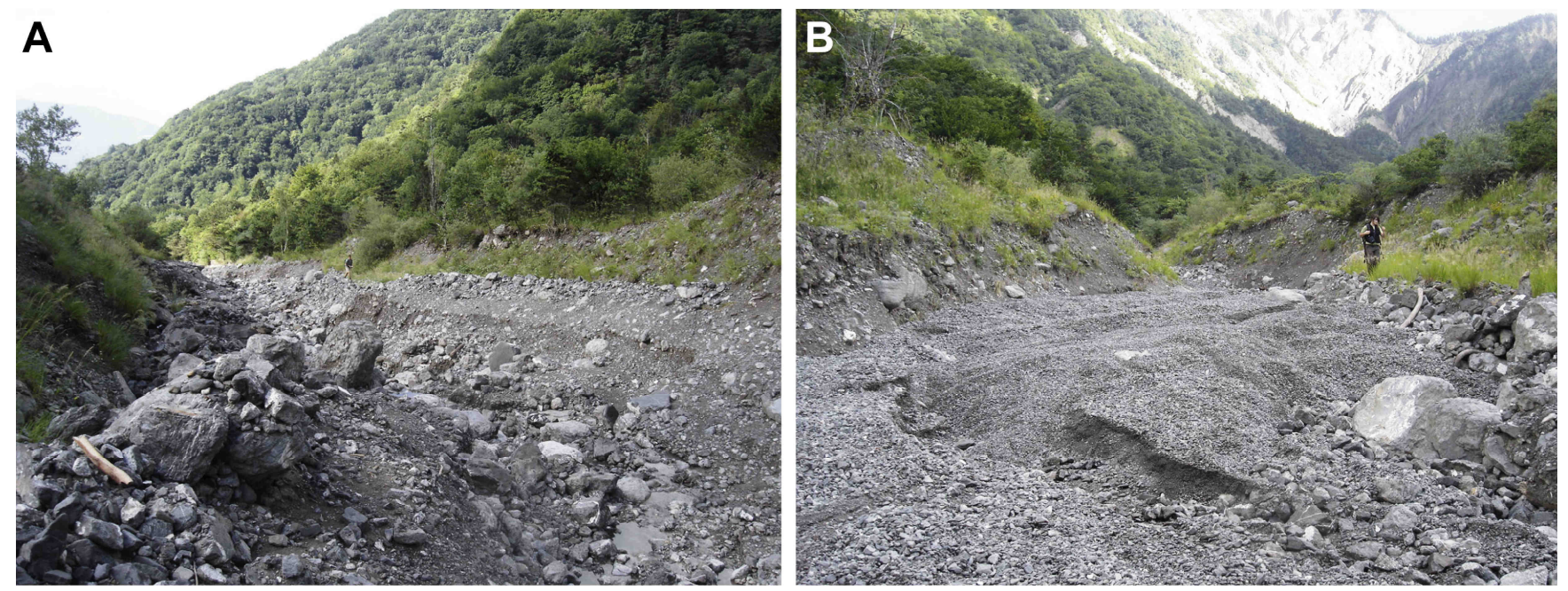

Fig. 2. Views looking downstream and upstream from XS 19 (Fig. 1) in the Manival study reach showing (A) debris-flow levees and coarse lags and (B) gravel wedges filling the U-shape debris-flow channel.

concrete check-dams are present along the upper part of the study reach between the surveyed cross-sections 24 and 39 (see Sect. 2.2.1). Before the 1970s, debris-flows propagated in the upper fan through several active channels, but to avoid the maintenance of check-dams along secondary channels, the ONF-RTM38 decided to concentrate debris-flows along one single channel constrained in the right-side of the fan by embankment works (gravel levees). Archive analysis of the Manival flood history during the last two centuries showed that the torrent can produce large debris-flows ranging from 10000 to $60000 \mathrm{~m}^{3}$ (Peteuil et al., 2008). Lopez Saez et al. (2011) presents further details on the debris-flow history of the Manival with these archives and the reconstruction of past debris-flow events using dendrogeomorphology. Since 2008, the Manival has produced one debris-flow each year depositing into the sediment trap.

\subsection{Sediment budget}

\subsubsection{Channel storage changes}

Multi-date topographic surveying of cross-sections were used for monitoring channel storage change in the study reach of the Manival torrent. Cross-sections were regularly spaced along the study reach, paying special attention to sample sections where channel deformation (scour-and-fill) was expected to be active. Thirty-nine cross-sections were deployed along the $1.8 \mathrm{-km}$ study reach of the Manival, giving a mean cross-section spacing of $46 \mathrm{~m}$ ( 3 times the mean active channel width) (Fig. 1). Wooden stakes on top of the channel banks were installed for cross-section benchmarking. Points were surveyed along transverse lines at each break of slope and each measurement point was marked with spray paint. This saved time during subsequent surveys by only measuring the active portion of the cross-section (the portion with paint marks was no longer visible). The mean point spacing was $1.3 \mathrm{pts}^{-1}$. Two days were required for surveying all of the cross-sections. Topographic surveys were measured with a total station (Leica Flexline TS02). The manufacturer's electronic distance measurement precision is $1.5 \mathrm{~mm} \pm 2 \mathrm{ppm}$, and the angular resolution is $7^{\prime \prime}$ or $3.4 \mathrm{~mm}$ of precision at a distance of $100 \mathrm{~m}$. The total station was benchmarked on permanent points of alluvial terraces.

The time frequency of topographic surveys was controlled by the occurrence of competent flow events (flow events that induce a morphological response of the channel), but the time-lapse between two successive events was sometimes too short to permit a perfect match between events and surveys. Eight post-event surveys were measured since Spring 2009, two surveys were done after debris-flow events of moderate intensity. It is important to mention that the debris-flows in this torrent are often in the form of multiple surges (eye witness reported 4 surges with 10 min intervals for one debrisflow). Therefore, topographic surveys capture the timeintegrated volume change of the torrent during the event. For this paper, the two types of events are characterised:

- A debris-flow event consisting of multiple surges, also including secondary bedload transport. Typical field indicators are unsorted levee, lobe, lag and terminal deposits with a fine sediment matrix. The secondary bedload transport can sometimes deposit sorted unconsolidated gravels in the thalweg.

- Bedload transport events refers to bedload processes occurring without debris-flows which regularly occur during intermittent flows and floods from low intensity rainfall and snowmelt. Typical field indicators are sorted, unconsolidated gravel deposits which sometimes 
develop into large wedges reaching bankfull. No debrisflow field indicators are present.

Cross-sections were used for quantifying volumes of erosion and deposition in the channel and back-calculating bedmaterial sediment transport using the morphological method (Ashmore and Church, 1998), widely applied for balancing sediment budgets in gravel-bed rivers (Ferguson and Ashworth, 1992; Martin and Church, 1995; Raven et al., 2009; Reid et al., 2007). Volumes of deposition $\left(V_{\mathrm{D}}\right)$ and erosion $\left(V_{\mathrm{E}}\right)$ between cross-sections are obtained by the following:

$V_{\mathrm{E}}=\frac{A_{\mathrm{E}(n)}+A_{\mathrm{E}(n+1)}}{2} L_{(n, n+1)}$

$V_{\mathrm{D}}=\frac{A_{\mathrm{D}(n)}+A_{\mathrm{D}(n+1)}}{2} L_{(n, n+1)}$

with $L$, the streamwise distance between the two crosssections $n$ and $n+1$, and $A_{\mathrm{E}}$ and $A_{\mathrm{D}}$ the cross-sectional area of erosion and deposition, respectively. The net storage change $\delta V$ between two surveys for the channel reach between two cross-sections is determined by the difference of the two volumes $V_{\mathrm{D}}$ and $V_{\mathrm{E}}$. The principle of mass conservation is used to determine the coarse sediment transport for each reach with:

$V_{\mathrm{o}}=V_{\mathrm{i}}-\delta V$

with $V_{\mathrm{o}}$ the sediment output and $V_{\mathrm{i}}$ the sediment input. Through monitoring sediment outputs at the downstream end of the study reach, the sediment transport and the sediment input can be determined for each sub-reach comprised between two cross-sections.

Uncertainties of erosion or deposition volume estimates for each sub-reach, $\sigma_{V}$, were calculated according to the propagation of uncertainty's law of Taylor (see Reid et al., 2007 for details):

$\sigma_{V}=\sqrt{\left(\sigma_{A_{n}}\left[\frac{\delta V}{\delta A_{n}}\right]\right)^{2}+\left(\sigma_{A_{n+1}}\left[\frac{\delta V}{\delta A_{n+1}}\right]\right)^{2}+\left(\sigma_{L_{n, n+1}}\left[\frac{\delta V}{\delta L_{n, n+1}}\right]\right)^{2}}$

The terms $\sigma_{A_{n}}$ and $\sigma_{A_{n+1}}$ respectively refers to errors associated with cross-sectional area of erosion or deposition at cross-sections $n$ and $n+1$, respectively, and $\sigma_{L_{n, n+1}}$ refers to the error associated with the distance between cross-sections $n$ and $n+1$. Cross-sectional areas of erosion $\left(A_{\mathrm{E}}\right)$ or deposition $\left(A_{\mathrm{D}}\right)$ were calculated by the following:

$A_{\mathrm{E}}=\sum_{i=1}^{n}\left(\frac{e_{i}+e_{i+1}}{2}\right) d_{i, i+1}$

$A_{\mathrm{D}}=\sum_{i=1}^{n}\left(\frac{f_{i}+f_{i+1}}{2}\right) d_{i, i+1}$

with $e_{i}$, the erosion depth at point $i, f_{i}$, the deposition depth at point $i$ and $d_{i, i+1}$ the distance between points $i$ and $i+1$.

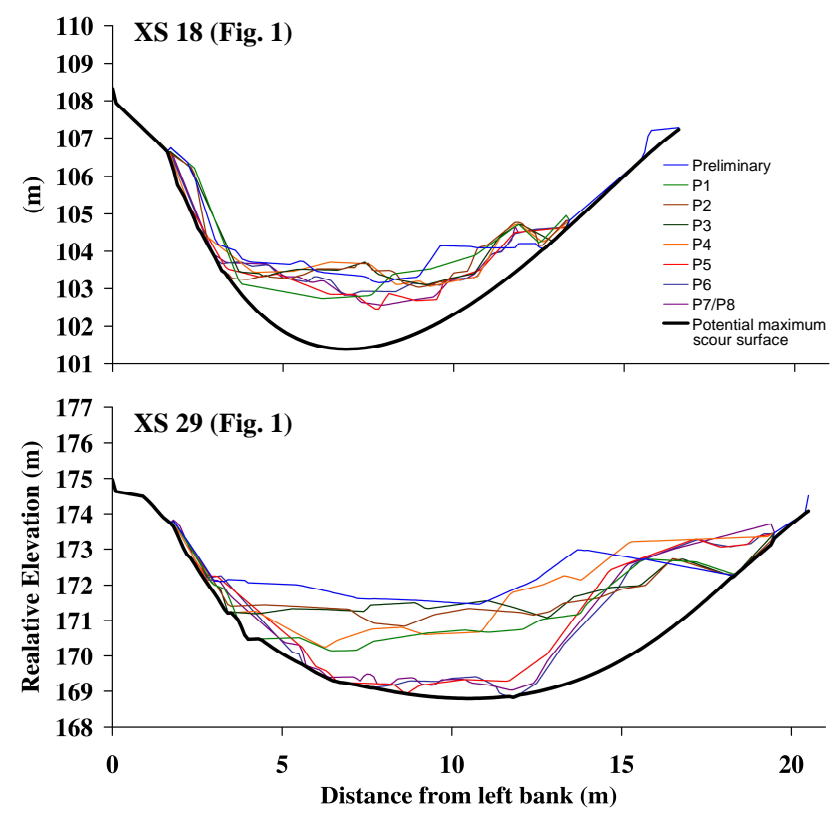

Fig. 3. Examples of Manival cross-section interpretations for determining the maximum debris-flow scour surface from best-fit polynomial curves; the XS 18 shows a maximum scour surface constrained only by the bank slopes, since the lowest elevation reached over the monitoring period did not excavate the channel up to the coarse lag layer; XS 29 shows a polynomial fit constrained by the lowest elevation over the monitoring period, since the presence of a coarse lag formation suggests that the channel will not deepen any further; thin coloured lines: cross-section resurveys over the monitoring period (P1-P8); thick black line: maximum debris-flow scour surface derived from polynomial fit.

Therefore, $\sigma_{A}$ used in Eq. (4) can be calculated using the Taylor's propagation of uncertainty with individual errors associated with $e_{i}, f_{i}$ and $d_{i, i+1}$. Erosion and deposition depths were calculated as elevation differences between two successive surveys. We assumed that the uncertainty of elevation measurements was equivalent to the $D_{84}$ of the bed surface grain-size distribution of the channel, which is approximately $5 \mathrm{~cm}$ for the Manival (measured by Wolman's pebble counts on $100+$ particles). A similar value was attributed to the error associated with the distance between two successive points, since the position of the prism during surveys is influenced by the roughness of the bed. The error associated with the curvilinear distance between two successive cross-sections was measured on a high-resolution digital terrain model (DTM) derived from an airborne laser scan (ALS) and was attributed a value of $1 \mathrm{~m}$, corresponding to the pixel size of the DTM.

\subsubsection{Sediment output}

The $25000-\mathrm{m}^{3}$ sediment trap was used for reconstructing sediment output by post-event topographic surveys. The trap is a 40-m wide and 130-m long sediment retention basin built 

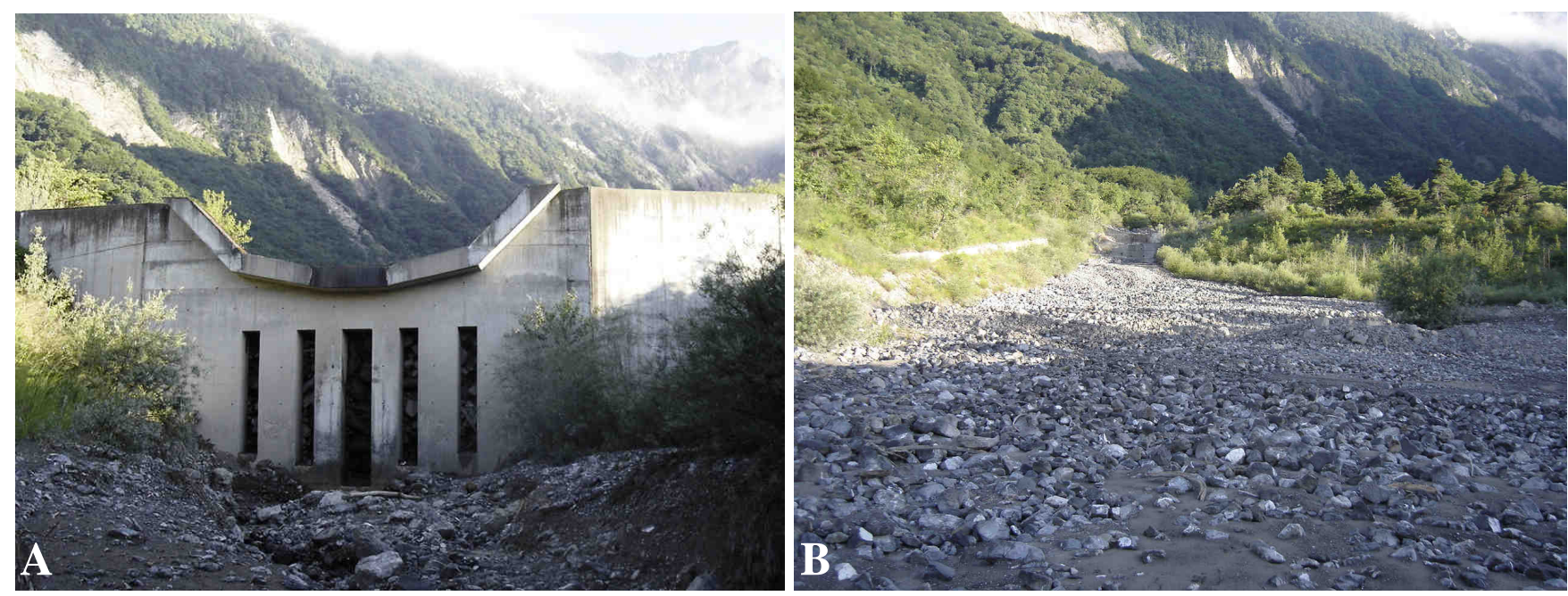

Fig. 4. View of the sediment trap after a debris-flow with (A) the dam blocked by the boulder front with tree debris and (B) the rest of the trap filled with finer sediment.

in 1926 and was closed since 1991 by a 5-m high concrete dam with sluice openings allowing water and fine sediment to pass through the dam, trapping only the coarse fraction of the sediment transport (Fig. 4). Since it can be expected that the trapping efficiency of the check-dam is not $100 \%$, resurveys of the sediment trap may only give a lower-bound estimate of the sediment output. Nevertheless, several observations lead us to consider sediment losses as negligible during the monitoring period. We observed that bedload deposits never reached the distal end of the trap during the recorded events. We also observed that debris-flows were slowly moving in the trap and they progressively reached the dam with a boulder front obstructing the sluice openings. The strong channel incision observed downstream from the dam, which indicates sediment starvation, also suggests a high trapping efficiency.

Most surveys of deposition in the sediment trap (4 of 5) were measured with the Leica TS02 total station. These surveys were subtracted from a terrestrial laser scan (TLS) of the empty sediment trap surveyed at the onset of the monitoring program. TLS surveys were measured with an ILRIS-3D (Optech Inc.) terrestrial laser scanner, with a $1535 \mathrm{~nm}$ laser giving a minimum footprint of $22 \mathrm{~mm}$ at $100 \mathrm{~m}$. This TLS has a laser repetition rate of $2000 \mathrm{~Hz}$, with a maximum range of about $1200 \mathrm{~m}$ for $80 \%$ reflectivity surfaces. The manufacturer's precisions of the TLS are $7 \mathrm{~mm}$ for distance, $8 \mathrm{~mm}$ for position and $80 \mu \mathrm{rad}$ for angle. The minimum point spacing is $2 \mathrm{~cm}$ at $1000 \mathrm{~m}$.

Overall point densities of the total station surveys were comprised of between 0.08 to $0.23 \mathrm{pts} \mathrm{m}^{-2}$. The deposition surface was smooth and conical, however, to get a more reliable representation of the deposition surface, we increased the density of surveyed points in areas with irregular topography and each break of slope was carefully sampled during the survey. Total station measurements were manually aligned with the previous TLS survey using 7 to 10 tie points (check-dams corners and edges) by using IM Align module on the software Polyworks ${ }^{\mathrm{TM}}$ of InnovMetric. The uncertainty associated with deposition volume estimates was assessed by calculating the propagated uncertainty related to two parameters: (i) the surface roughness which was attributed to a value corresponding to the $D_{75}$ of the surface grain-size distribution for debris-flow deposits $(0.07 \mathrm{~m})$ and bedload deposits $(0.05 \mathrm{~m})$, and (ii) the standard deviation of alignment error of the tie points which ranges from 0.05 to $0.10 \mathrm{~m}$.

One post-event survey was measured with the TLS. For the sediment trap, TLS surveys required less than one hour with a final point spacing less than $2 \mathrm{~cm}$ and a maximum root-meansquare error (RMS) between the multi-date cloud points of $\pm 0.02 \mathrm{~m}$ (detailed TLS methods are presented in Sect. 2.3).

Sediment trap surveys were measured during the crosssection survey campaign, except when sediment deposition was not visible in the sediment trap or when a substantial part of the deposit was removed by dredging operations. The sediment trap is managed by a private company in charge of dredging operations to maintain a full capacity over time. Generally, the time lapse between the flow event and the dredging works was long enough to implement a topographic survey. For three out of eight times, the trap was disturbed after small floods. The outputs in these situations had to be estimated according to sediment yields determined from crosssection surveys.

\subsection{Sediment supply from low-order headwaters}

The sediment supply from headwaters was monitored by TLS resurveys and an airborne laser scan survey (ALS) for three study areas (Fig. 1): a small active first-order headwater entrenched into a talus slope below a limestone cliff with $400 \mathrm{~m}$ relief (denoted as S1), and two upstream second- and 
third-order steep-slope channel reaches confined between eroding hillslopes directly delivering sediments to the channel by shallow landsliding and hillslope debris-flows initiated on talus slopes (denoted, respectively, as S2 and S3). General characteristics of these 3 areas are presented in Table 2. The S1 site was accessible on a trail and can be seen from a view point with optimal angle and coverage. S2 and S3 sites were chosen because of having safe viewable locations and they are reaches between the first-order to the main torrent channel.

The TLS data were collected on a seasonal basis during 2009 (April, July, August and November). Scanning positions for S1 were taken both within the channel and across the upper catchment using 2 to 8 locations with distances ranging from 2 to $600 \mathrm{~m}$. S2 required two to three scanning positions with distances of 20 to $450 \mathrm{~m}$. S3 required one position at a maximum distance of $250 \mathrm{~m}$. In order to save time in the field, long range scans had a maximum point spacing of $0.1 \mathrm{~m}$ which can vary according to shadow effects (channel areas hidden by terrain obstructions from the laser).

The ALS survey for the entire catchment was flown by helicopter in June 2009 by a private company (Sintegra) using a $200 \mathrm{kHz}$ Riegl LMS Q560 laser scanner. The flight elevation fluctuated between 450 and $650 \mathrm{~m}$ above ground, with a maximum instantaneous scan angle of 25 degrees, giving a laser footprint range between 0.16 and $0.24 \mathrm{~m}$ for flat terrains. The mean density of the filtered point cloud was $6.9 \mathrm{pts} \mathrm{m}^{-2}$ and the altimetric and planimetric errors were 0.10 and $0.15 \mathrm{~m}$, respectively. However, with the raw LiDAR data for the 3 sites, sparse vegetation cover was manually cleaned preserving a point density up to $30 \mathrm{pts} \mathrm{m}^{-2}$. Manually cleaning refers to identifying and selecting the backscattering from vegetation in the scan's point cloud and deleting it rather than using automatic filters.

The multi-date scans (ALS and TLS) were merged and aligned on IM Align module on the software Polyworks ${ }^{\mathrm{TM}}$ of InnovMetric. With the IM Align, identifiable permanent structures such as check-dams can be selected as tie points for different scans, the point clouds of these features can then be aligned with the Automatic Iterative Closest Point algorithm (Besl and McKay, 1992). Digital Elevation Models (DEMs) with $0.1 \mathrm{~m}$ resolution were created by ordinary kriging interpolation for the TLS data. This interpolation method was chosen because the resulting relief representation was qualitatively identified as the most reliable to the field morphology. The DEM from the ALS data was created with a linear drift kriging for smoothing high density linear swaths of points in the airborne scans. These DEM layers were used to create classical DEM of differences (DoD) for calculating volumes of erosion and deposition. The uncertainty associated with volume estimates was assessed by using IM Align to find the maximum RMS of alignments between the multi-date point clouds $( \pm 0.08 \mathrm{~m})$ covering areas with permanent structures (Iavarone and Vagners, 2003; Rabatel et al., 2008).

\subsection{Initial channel storage quantification}

The volume of sediment storage in the main channel of the torrent was estimated at the onset of the monitoring. The objective was to determine the boundary conditions of the captured storage changes over the monitoring period and to evaluate the fraction of the total alluvial sediment reservoir that is remobilised during debris-flows. The Manival torrent has limited lateral migration with well-defined channel banks where the susceptible areas are controlled by the engineering works of the RTM services. This provides realistic estimations of connected channel storage to the sediment trap.

Channel storage at $t_{0}$ (6 July 2009) was obtained by the "sloping local base level" (SLBL) method (Jaboyedoff and Derron, 2005). The SLBL has been initially defined as a surface above which has rocks that are assumed to be erodible by landsliding (Jaboyedoff et al., 2004) and the method was adapted to estimate the sediment infilling of glacial $U$-shape valleys (Jaboyedoff and Derron, 2005; Otto et al., 2009). The general principle is to deepen DTM pixels included in the alluvial fill by an iterative routine until an assumed bedrock surface shape is reconstructed. The surface geometry was determined by quadratic equations. Cross-sections in the Manival are located in the main channel of the alluvial flat where a U-shape is most likely to form (validated with multi-date cross-section overlays). Therefore, it seemed relevant to use the SLBL method for quantifying the volume of erodible sediment by debris-flows along the main channel of the Manival. In this case, the maximum scour surface is not controlled by bedrock because the thickness of alluvial fill is much greater than the maximum potential scouring depth of debris-flows (which we estimated around 4 to $5 \mathrm{~m}$ ). The main channel is entrenched in the alluvial fan with a general range of thickness from 10 to $30 \mathrm{~m}$.

ALS-derived DTMs were used with a grid size of one metre to run the SLBL routine (Jaboyedoff and Derron, 2005). The first step was to edit manually the limits of in-channel depositional landforms. This was done by mapping the spatial extent of the active channel using both $12.5-\mathrm{cm}$ resolution digital orthophoto (Aerodata International Surveys) and a hillshade representation of unfiltered DTMs with vegetation manually cleaned. The second step was to assign values for two user-defined parameters of the SLBL routine which constrain the shape of the reconstructed parabola. The first is the maximum depth of the alluvial storage and the second is the maximum curvature of the debris-flow scour surface. These two parameters were determined from the interpretation of the cross-section shapes of the torrent. For each cross-section surveyed in the field with the total station, we interpolated the maximum debris-flow scour surface by fitting a polynomial curve to the bank slopes on each side of the active channel, assuming that the bank profile is controlled by debris-flow erosion. We also constrained the bestfit polynomial with the lowest elevation observed at each cross-section during the monitoring period, providing that 
Table 2. General features of the three headwaters in the Manival catchment dedicated to the monitoring of sediment supply from hillslopes by LiDAR resurveys.

\begin{tabular}{llll}
\hline & $\mathrm{S} 1$ & $\mathrm{~S} 2$ & $\mathrm{~S} 3$ \\
\hline Length of the surveyed reach $(\mathrm{m})$ & 140 & 95 & 170 \\
Drainage area $\left(\mathrm{km}^{2}\right)$ & 0.03 & 0.17 & 0.52 \\
Channel slope $(\%)$ & 67 & 55 & 45 \\
Stream order* & 1 & 2 & 3 \\
Scanned surface $\left(\mathrm{m}^{2}\right)$ & $1600-1900$ & 660 & 840 \\
Number of check-dams & 0 & 5 & 11 \\
\hline
\end{tabular}

* Based on LiDAR-derived DTM stream network.

this lowest elevation corresponds to the presence of older highly consolidated coarse lag (similar in strength to soft bedrock) preventing deeper scour during subsequent flows (Fig. 3). This procedure allowed for calculating the sediment storage in the main channel and controlling the SLBLderived sediment volume.

\subsection{Rainfall monitoring}

Two tipping bucket rain gauges (Rainwise Inc.) with a 196$\mathrm{mm}$ diameter and resolutions of 0.12 and $0.16 \mathrm{~mm}$ were used for rainfall monitoring in the catchment. The rain gauges are connected to a data logger recording instantaneous time of tips and allowing computation of rainfall intensity at varying time intervals. The first was installed in October 2008 at the apex of the alluvial fan (Fig. 1), at an elevation of $860 \mathrm{~m}$ a.s.l. The second was installed on the catchment ridge in July 2010 at an elevation of $1490 \mathrm{~m}$ a.s.l. We chose open sites easily accessible from the road to facilitate regular visits of the instrument for maintenance and data collecting. The two rain gauges are spaced $1.1 \mathrm{~km}$ apart, and they both generally showed similar rainfall readings in the Manival during the summer. From autumn to spring the upper rain gauge is susceptible to snow cover and melt. Therefore, the lower rain gauge was used for analysis because of its continuous recording from the beginning of the monitoring program.

\section{Results}

\subsection{Rainfall and channel responses}

Despite rainfall of low to moderate intensity during the monitoring period (less than one to two year return period) (Table 3, Fig. 5), considerable channel responses were observed along the torrent. Eight periods of significant geomorphic activity were observed along the study reach between July 2009 and December 2010 (denoted as P1 to P8), two of these periods being characterised by the occurrence of a debris-flow (August 2009 and June 2010). The maximum daily rainfall was observed during $\mathrm{P} 1$, with a value of $34.7 \mathrm{~mm}$. A frequency analysis of maximum daily rainfall based on the nearest long-term rainfall time series (Météo France station of Saint-Hilaire-du-Touvet, 1964-2010, elevation of $970 \mathrm{~m}$ a.s.l, located $5 \mathrm{~km}$ from the Manival, on the same mountain side) gave a 10 -yr daily rainfall of $88 \mathrm{~mm}$ ( $90 \%$ confidence interval: 83-94 mm). This calculation was based on a monthly sampling of maximum daily rainfall to increase the size of the sample and to provide a more accurate estimate of extreme rainfall (Djerboua, 2001; Djerboua and Lang, 2007). According to the fitted probability law, the return period of the maximum $24 \mathrm{~h}$ rainfall observed during the monitoring period was $1.0 \mathrm{yr}$. The maximum 5min rainfall intensity was recorded during $\mathrm{P} 6$, with a value of $79 \mathrm{~mm} \mathrm{~h}^{-1}$. This high-intensity storm event did not initiate any debris-flow in the catchment. Debris-flows occurred during P1 and P5, when maximum rainfall intensities were 49 and $25 \mathrm{~mm} \mathrm{~h}^{-1}$, respectively. The minimum rainfall intensity associated with an observable channel response was $7 \mathrm{~mm} \mathrm{~h}^{-1}$ during P3 and P8.

\subsection{Torrent sediment budgets}

Sediment budgets reconstructed for the Manival during the eight investigated periods are summarized in Table 4. Unit volume changes (including yield rates) for these periods are reconstructed from the cross-section resurveys (Fig. 6). The high yield rates from the debris-flows (P1 and P5) identifies the extent of entrainment which can divide the torrent channel into two sections, the proximal and distal reach in reference to the apex of the alluvial fan. Sediment transport volumes were computed by first cumulating the unit volume change and then they are readjusted so that the output volumes match the sediment trap volumes (Fig. 6).

During P1 a debris-flow occurred, the geomorphic activity of the main channel was only driven by a short-duration convective storm which occurred on 25 August 2009. With the storm burst defined as a continuous rainfall according to a 5-min time step, the duration was $45 \mathrm{~min}$ with a total of $11 \mathrm{~mm}$ and a maximum 5-minute intensity of $49 \mathrm{~mm} \mathrm{~h}^{-1}$. Considerable channel erosion was observed (Fig. 7) in the proximal part of the study reach from the apex of the alluvial fan, while the distal part had depositional characteristics 
Table 3. Summary values of rainfall for each monitoring period of channel storage changes; mean and maximum intensities are calculated for a $5 \mathrm{~min}$ time-interval; rainfall data from the rain gauge at the Manival ridge are indicated in brackets and showed similar values to the rain gauge located near the main channel.

\begin{tabular}{|c|c|c|c|c|c|c|}
\hline $\begin{array}{l}\text { Survey } \\
\text { time period }\end{array}$ & $\begin{array}{l}\text { Period } \\
\text { ID }\end{array}$ & $\begin{array}{l}\text { Total intensity } \\
\text { rainfall }(\mathrm{mm})\end{array}$ & $\begin{array}{r}\text { Maximum } 24 \mathrm{~h} \\
\text { rainfall }(\mathrm{mm})\end{array}$ & $\begin{array}{r}\text { Mean storm } \\
\text { intensity }\left(\mathrm{mm} \mathrm{h}^{-1}\right)\end{array}$ & $\begin{array}{r}\text { Maximum burst } \\
\left(\mathrm{mm} \mathrm{h}^{-1}\right)\end{array}$ & Debris-flow \\
\hline 6 Jul 2009-28 Aug 2009 & $\mathrm{P} 1$ & 93 & 34.7 & 3.2 & 49 & 25 Aug 2009 \\
\hline 30 Aug 2009-7 Oct 2009 & $\mathrm{P} 2$ & 24 & 14.5 & 2.8 & 17 & \\
\hline 8 Oct 2009-12 Nov 2009 & P3 & 101 & 16.6 & 1.9 & 7 & \\
\hline 13 Nov 2009-1 June 2010 & $\mathrm{P} 4$ & 239 & 32.2 & 2.1 & 10 & \\
\hline 2 Jun $2010-8$ Jun 2010 & P5 & 26 & 24.4 & 6.2 & 25 & 6 Jun 2010 \\
\hline 9 Jun $2010-8$ Oct 2010 & P6 & $174(170)$ & $21.3(21.0)$ & $3.0(2.7)$ & $79(35)$ & \\
\hline 14 Oct $2010-25$ Nov 2010 & $\mathrm{P} 7$ & $150(76)$ & $22.3(23.0)$ & $2.2(2.0)$ & $17(6)$ & \\
\hline 25 Nov 2010-10 Dec 2010 & P8 & 33 & 19.4 & 2.0 & 7 & \\
\hline
\end{tabular}

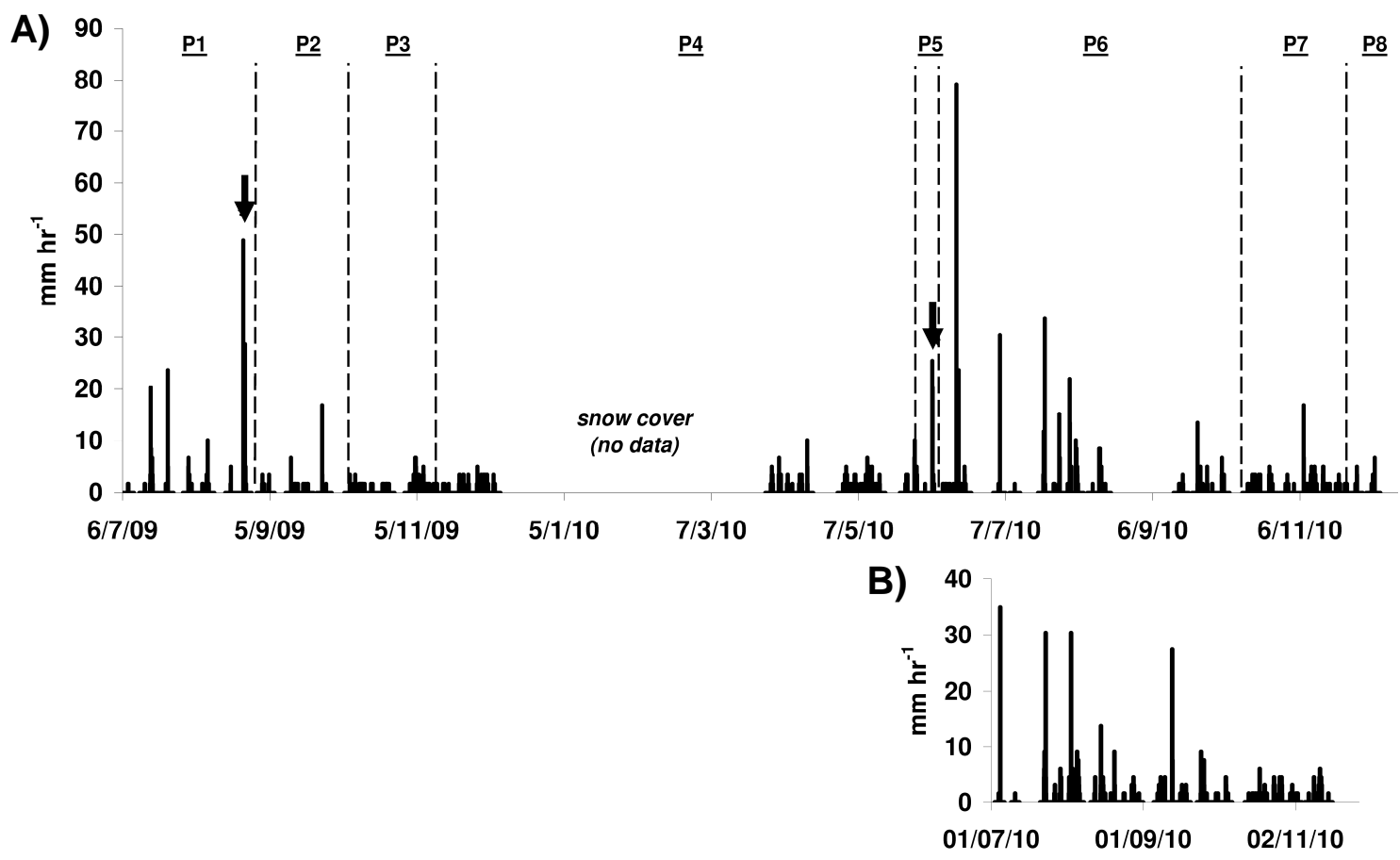

Fig. 5. Maximum rainfall intensity (five-minute resolution) observed for the Manival from (A) the lower study site rain gauge and (B) the upper study site rain gauge; cross-section surveys are indicated by dotted lines; the arrows indicate debris-flow occurrence.

(Fig. 7). Maximum local scour reached $2.9 \mathrm{~m}$. A net storage loss of $2034 \mathrm{~m}^{3} \pm 199$ was obtained, which was equivalent to the sediment output captured by the TLS survey of the sediment trap $\left(1873 \mathrm{~m}^{3} \pm 62\right)$. Therefore, sediment input from the upper catchment could be considered as very low (not greater than $63 \mathrm{~m}^{3}$ given uncertainties of storage changes and output) and most of the sediment yield was supplied by channel scouring along the main channel. There were no signs of a debris-flow upstream from the proximal reach. This suggests that the debris-flow initiated in the proximal reach of the main channel.
During the P2 period (30 August to 7 October 2009), a succession of small rainfall events with a maximum intensity of $17 \mathrm{~mm} \mathrm{~h}^{-1}$ induced moderate channel changes related to bedload transport, with a general storage gain of $789 \mathrm{~m}^{3} \pm 84$, homogeneously distributed along the study reach. A substantial part of the sediment loss from the August 2009 debris-flow was recharged during P2 (Fig. 6) by the deposition of gravel wedges (the storage recharge was estimated to be between 33 and $41 \%$ given the uncertainty of the volume calculation). The sediment trap stayed empty during this period, meaning that an important amount of 

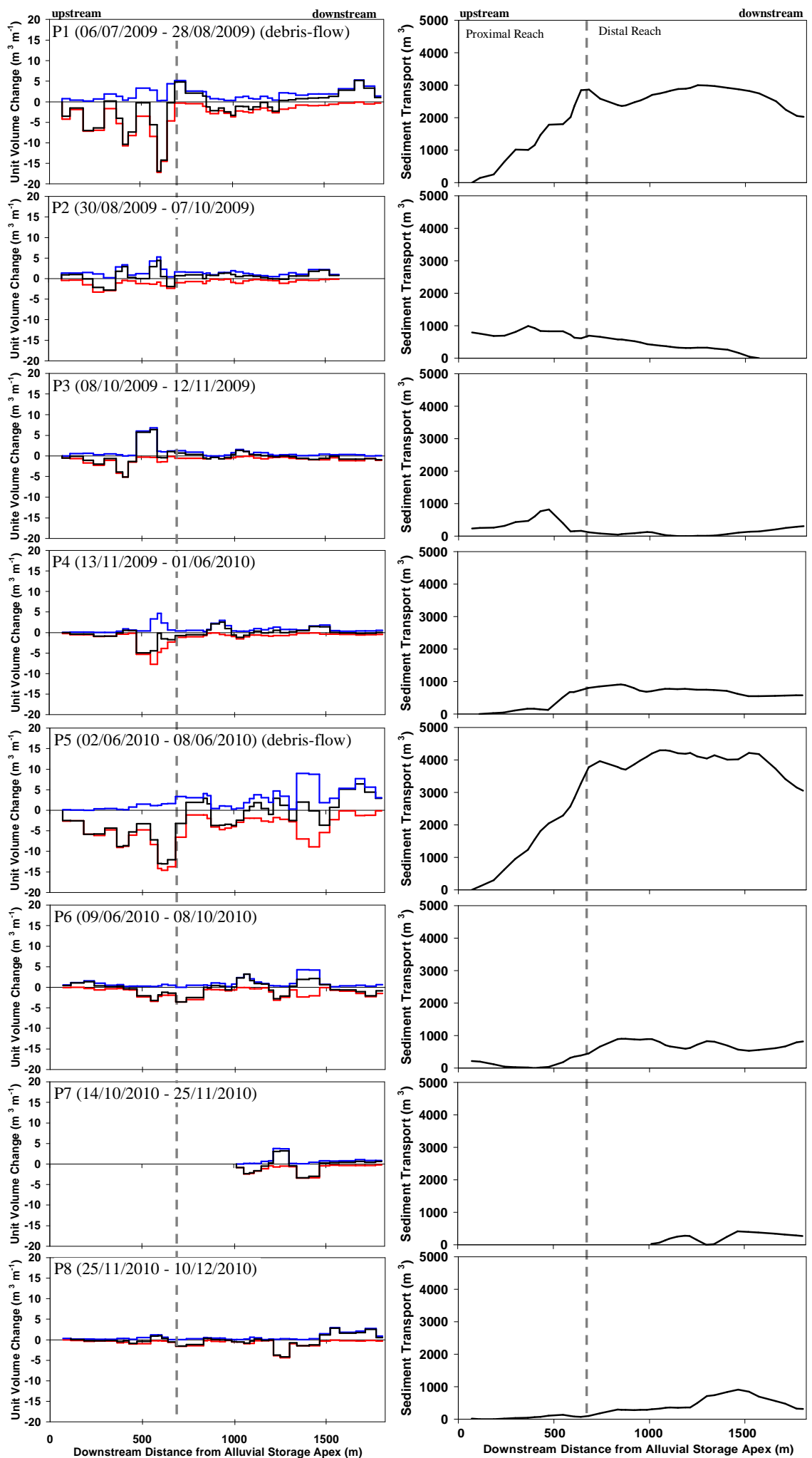

Fig. 6. In-channel storage changes per unit length and sediment transport in the Manival Torrent for each time period investigated by crosssection and sediment trap resurveys; the general debris-flow entrainment extent (proximal reach) is indicated by the dashed grey line; blue line: deposition; red line: erosion; black line: net storage change. 
Table 4. Sediment budget for the Manival Torrent obtained from cross-section and sediment trap resurveys; sediment inputs were backcalculated from storage changes and outputs; uncertainties of channel erosion and deposition are calculated from the Taylor's law of uncertainty propagation; storage change uncertainty is the sum of erosion and deposition uncertainties; sediment output uncertainty is calculated from individual errors associated with topographic surveys; ranges of values proposed for sediment output (when a topographic survey of the sediment trap is not available) or input are derived from storage change uncertainty.

\begin{tabular}{lrrrrrr}
\hline $\begin{array}{l}\text { Study } \\
\text { period }\end{array}$ & $\begin{array}{r}\text { Period } \\
\text { ID }\end{array}$ & $\begin{array}{r}\text { Sediment } \\
\text { Input }\left(\mathrm{m}^{3}\right)\end{array}$ & $\begin{array}{r}\text { Storage } \\
\text { Change }\left(\mathrm{m}^{3}\right)\end{array}$ & $\begin{array}{r}\text { Channel } \\
\text { Erosion }\left(\mathrm{m}^{3}\right)\end{array}$ & $\begin{array}{r}\text { Channel } \\
\text { Deposition }\left(\mathrm{m}^{3}\right)\end{array}$ & $\begin{array}{r}\text { Sediment } \\
\text { Output }\left(\mathrm{m}^{3}\right)\end{array}$ \\
\hline 6 Jul 2009-28 Aug 2009 & P1 & $0-63$ & $-2034( \pm 199)$ & $5232( \pm 136)$ & $3199( \pm 63)$ & $1873( \pm 62)$ \\
30 Aug 2009-7 Oct 2009 & P2 & $736-842$ & $789( \pm 84)$ & $1409( \pm 31)$ & $2197( \pm 53)$ & 0 \\
8 Oct 2009-12 Nov 2009 & P3 & $198-260$ & $-73( \pm 66)$ & $1546( \pm 36)$ & $1473( \pm 31)$ & $266-338$ \\
13 Nov 2009-1 Jun 2010 & P4 & $0-36$ & $-580( \pm 81)$ & $1961( \pm 45)$ & $1372( \pm 36)$ & $535-625$ \\
2 Jun 2010-8 Jun 2010 & P5 & $0-537$ & $-3052( \pm 272)$ & $7658( \pm 178)$ & $4605( \pm 93)$ & $3320( \pm 176)$ \\
9 Jun 2010-8 Oct 2010 & P6 & $174-246$ & $-608( \pm 82)$ & $2246( \pm 46)$ & $1637( \pm 36)$ & $773-865$ \\
14 Oct 2010-25 Nov 2010 & P7 & $0-49$ & $-267( \pm 35)$ & $921( \pm 20)$ & $685( \pm 15)$ & $226( \pm 34)$ \\
25 Nov 2010-10 Dec 2010 & P8 & $0-76$ & $-306( \pm 51)$ & $1351( \pm 29)$ & $1056( \pm 23)$ & $515( \pm 41)$ \\
6 Jul 2009-10 Dec 2010 & & $\mathbf{1 1 0 8 - 2 1 0 9}$ & $-\mathbf{6 1 4 7}( \pm \mathbf{8 7 0})$ & & & $\mathbf{7 1 9 5 - 8 0 7 5}$ \\
\hline
\end{tabular}

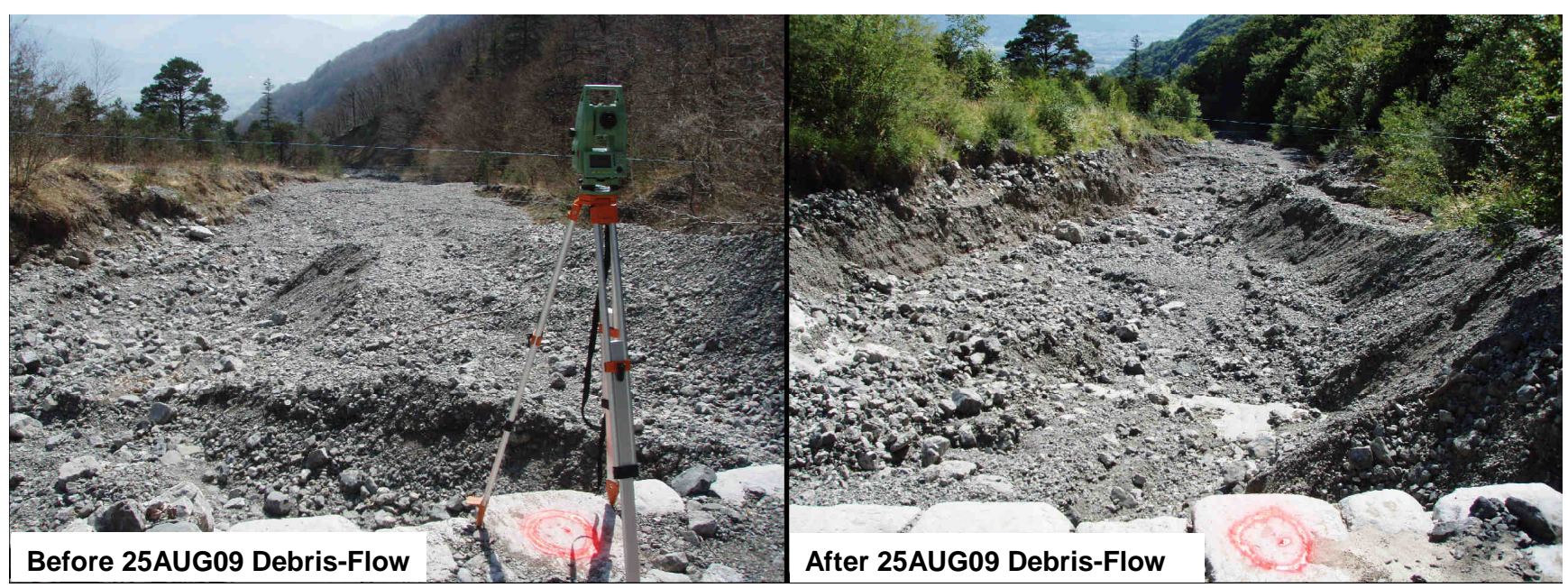

Fig. 7. Photo sequence displaying channel scouring of the August 2009 debris-flow in the main channel of the Manival; views looking downstream.

sediment had been delivered by the upper catchment (calculated between 736 and $842 \mathrm{~m}^{3}$ ), despite the low rainfall. The main channel functioned as a sediment trap, capturing gravels coming from the upper catchment. A similar pattern of rainfall was observed during $\mathrm{P} 3$, with long duration and low intensity rainfall events, typical of the autumn season. A net storage loss of $89 \mathrm{~m}^{3} \pm 66$ was obtained. The sediment trap was disturbed by dredging operations; however, assuming zero input, the output could be estimated from the sediment transport trend to be $266-338 \mathrm{~m}^{3}$ and a recharge from the upper catchment of $198-260 \mathrm{~m}^{3}$. Channel responses were not very important, except in a small proximal reach where considerable gravel wedges accumulated in the channel, generating $1.2 \mathrm{~m}$ of deposition locally. Those gravel deposits were supplied by both channel scour- ing in the proximal main channel and sediment supply from the upper catchment. The P4 period (13 November 2009 to 1 June 2010) included small rainfall events with low intensity (maximum of $10 \mathrm{~mm} \mathrm{~h}^{-1}$ ) during the early spring. A net storage loss of $580 \mathrm{~m}^{3} \pm 81$ was captured, without any sign of debris-flow activity. Again, the sediment trap was disturbed by dredging operations; however, assuming zero sediment input, the output could be estimated from the sediment transport trend to be 535-625 $\mathrm{m}^{3}$ and a recharge from the upper catchment of 0-36 $\mathrm{m}^{3}$. The most remarkable channel response was observed in the proximal reach, where a considerable remobilisation of the gravel wedges deposited during the $\mathrm{P} 3$ period was observed. It is possible that those gravels were transported down to the sediment trap since no significant channel deposition was observed in the distal reach. 
The most important debris-flow of the monitoring period occurred during P5 period which was initiated by a short duration convective storm that occurred the 6 June 2010. With the storm burst defined as a continuous rainfall according to a 5-min time step, the duration was $2.3 \mathrm{~h}$ with a total of $21 \mathrm{~mm}$ and a maximum 5-min intensity of $25 \mathrm{~mm} \mathrm{~h}^{-1}$. The general pattern of erosion and deposition along the main channel was very similar to the one of the August 2009 debris-flow (Fig. 6). A net storage loss of $3052 \mathrm{~m}^{3} \pm 272$ was obtained, which is equivalent to the sediment deposition in the trap, measured at $3320 \mathrm{~m}^{3} \pm 176$. Channel scouring of the proximal reach supplied most of the sediment output and the direct contribution of the upper catchment to the sediment yield was negligible. The debris-flow grew in volume along a reach of $600 \mathrm{~m}$ length and $18 \%$ slope, contributing $\sim 4000 \mathrm{~m}^{3}$ to the distal reach and sediment trap. Despite the high intensity of the rainfall, the sediment supply from the upper catchment was low (higher-bound estimate of $537 \mathrm{~m}^{3}$ ). However, mud marks were observed upstream from the scoured reaches indicating that fine sediments were already present. They most likely originated from hillslope runoff and bank erosion.

The channel response after the June 2010 debris-flow was different than what was observed after the August 2009 event. The debris-flow occurred in early summer; for the rest of the summer (P6), a series of high intensity rainfall (range: 20-79 $\mathrm{mm} \mathrm{h}^{-1}$ ) did not produce any debris-flows. The P6 period was the most active in terms of rainfall, but not the most sensitive in terms of geomorphic response. The proximal reach continued to scour, whereas some thin gravel wedges were deposited in the distal reach (Fig. 6). A net storage loss of $608 \mathrm{~m}^{3} \pm 82$ was obtained. The sediment trap was disturbed; however, the output was estimated to be $773-865 \mathrm{~m}^{3}$ and a recharge from the upper catchment of $174-246 \mathrm{~m}^{3}$ was obtained. The August 2009 debris-flow lag and levee deposits were eroded during this period and accumulated into gravel wedges along the distal reach. Throughout autumn 2010 (P7 and P8), these gravel wedges gradually mobilized downstream into the sediment trap without substantial sediment supply from the upper catchment (Fig. 6).

\subsection{Sediment supply from first-order headwaters}

Seasonal repeat TLS surveys of Manival headwaters from April to November 2009 revealed important elevation changes over time. At site S1, located in Fig. 1, four DEMs of difference (the subtraction of a post and prior DEM) were produced during the period. From April to June and from June to August, the most striking change was a strong decrease of elevation in the proximal part of the gully, which had reached 3 to $5 \mathrm{~m}$ locally (Fig. $8 \mathrm{a}$ and b). The loss in elevation was most dramatic between June and August even with rockfall deposits occurring just upslope. During this period, no convective storms occurred and no geomorphic activity was observed along the main channel of the Manival.
Moreover, no gain of elevation was observed in the distal part of the gully (confirmed with painted field marks), and it is difficult to imagine long travel distances of sediment without any significant rainfall. Therefore, the captured elevation changes in the proximal part of the gully should have been driven by the melting of buried snow accumulations of the winter which were mixed and recovered by rockfall deposits coming from the active rock wall (Fig. 8c and d). Snow accumulations in shaded gullies resulted partly from snow avalanches, which are very frequent in the upper catchment of the Manival. The resulting DEMs of difference could not be integrated in the sediment budget analysis since most of the lost volume concerned snow (total volume loss: $\left.754 \mathrm{~m}^{3} \pm 145\right)$.

TLS resurvey of the S1 site during August (corresponding with P1) showed that a talus slope failure occurred in the proximal zone (Fig. 9a). An erosion of $266 \mathrm{~m}^{3}$ took place at the talus slope with $268 \mathrm{~m}^{3}$ depositing 40 to $80 \mathrm{~m}$ down the gully. The net deposition of $2 \mathrm{~m}^{3} \pm 87$ shows very little input from the rock wall. No morphological change was observed further downstream in the gully. There were not any rainstorms or sustained rainfall throughout August 2009 until the debris-flow event. The small talus slope failure was most likely initiated during the storm event of August 2009 that generated a debris-flow in the main channel of the Manival. The remobilised sediments remained in the distal part of the headwater channel and for the rest of the monitoring period. Even though the S1 site was disconnected from the channel, other first-order headwaters were active and connected to the channel and the S2 and S3 site (locations in Fig. 1).

TLS resurveys of S2 and S3 sites during August 2009 (P1 period) showed net erosion in the upper reach (S2, Fig. 9c) and net deposition in the lower reach (S3, Fig. 9e). No signs of a debris-flow were observed along these two reaches and the morphological changes were induced by bedload transport. The confluences of the numerous left-bank (east-bank) gullies of the S3 site stayed unchanged, without any fan formation related to the deposition of hillslope debris-flows in the main channel. Laser scan observations for the following period (from August to November 2009, P2 and P3) showed the inverse situation, with net deposition in the upper reach (Fig. 9d) and net erosion in the lower reach (Fig. 9f). As for the previous period, these responses were related to bedload transport. During 2010, little geomorphic activity was observed in the 3 sites and no TLS surveys were implemented.

We acknowledge the fact that there may be an influence of check-dams (visible in Fig. 9c-f) on sediment transfer. There were not any second- or third-order uncontrolled reaches available at the study site to make any comparisons. Furthermore, observations showed that erosion and deposition takes place at varying check-dam spacing for both debris-flow and bedload transport. Therefore, with the observed complexity and limited information we cannot make a detailed analysis on the effect of check-dams. 

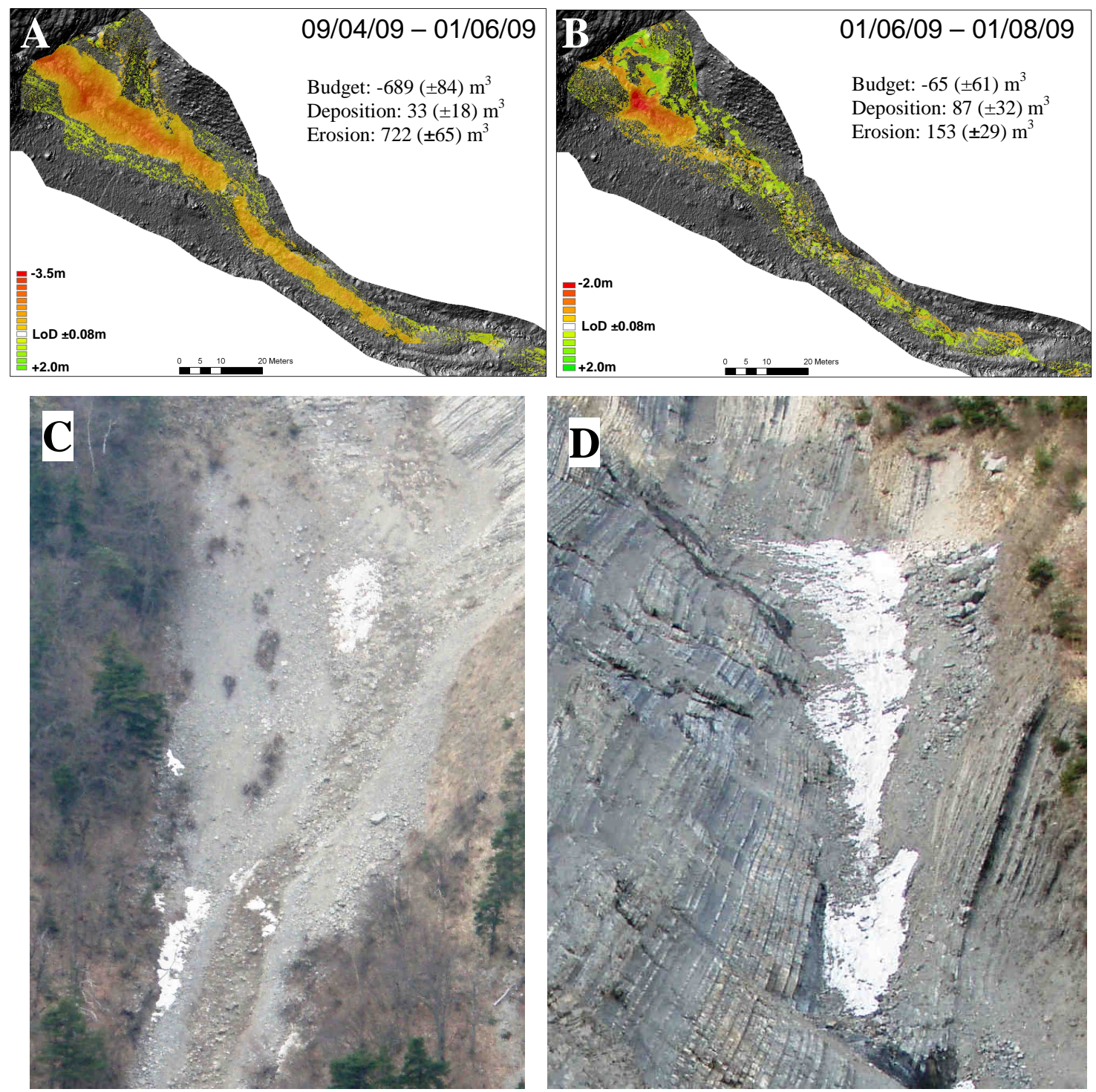

Fig. 8. Snowmelt indicated by DEM of differences derived from TLS and ALS resurveys of the S1 site on the Manival from April to June 2009 (A) and June to August 2009 (B); LoD: level of detection of significant elevation change based on the RMSE of the merging process. View (C) is of the proximal zone of the S1 site where snow was mostly mixed in the deposits; view (D) is of the proximal zone of a typical first-order gully of the Manival showing snow accumulation partially covered by rockfall deposits.

\subsection{Fluctuating channel storage over time}

The initial channel storage for the Manival torrent at the onset of the monitoring estimated to be $35500 \mathrm{~m}^{3}$ according to the SLBL method. This value is in good agreement with the storage volume estimated by cross-section interpretation of the maximum debris-flow scouring surface, which gave a total volume of $31500 \mathrm{~m}^{3}$. The storage estimates were subdivided in 3 functional reaches according to the geomorphic responses observed during the monitoring period: the proximal reach where maximum channel scouring was observed, holds an initial storage of $13500 \mathrm{~m}^{3}$, the transport reach where an equilibrium was observed between erosion and deposition, with $13800 \mathrm{~m}^{3}$ of storage, and the lower reach where deposition was higher than erosion, with a storage of $4200 \mathrm{~m}^{3}$. After two years of monitoring, the total sediment storage decreased to $25400 \mathrm{~m}^{3}$ (Fig. 10) with the proximal reach losing $7600 \mathrm{~m}^{3}$, the transport reach losing $700 \mathrm{~m}^{3}$, and the lower reach gaining $1400 \mathrm{~m}^{3}$ (Fig. 11). Most of the storage loss was induced by the two debris-flows, which remobilised $14 \%$ of the in-channel sediment reservoir. If only the proximal reach is considered, the two debris-flows evacuated $56 \%$ of the available storage. 


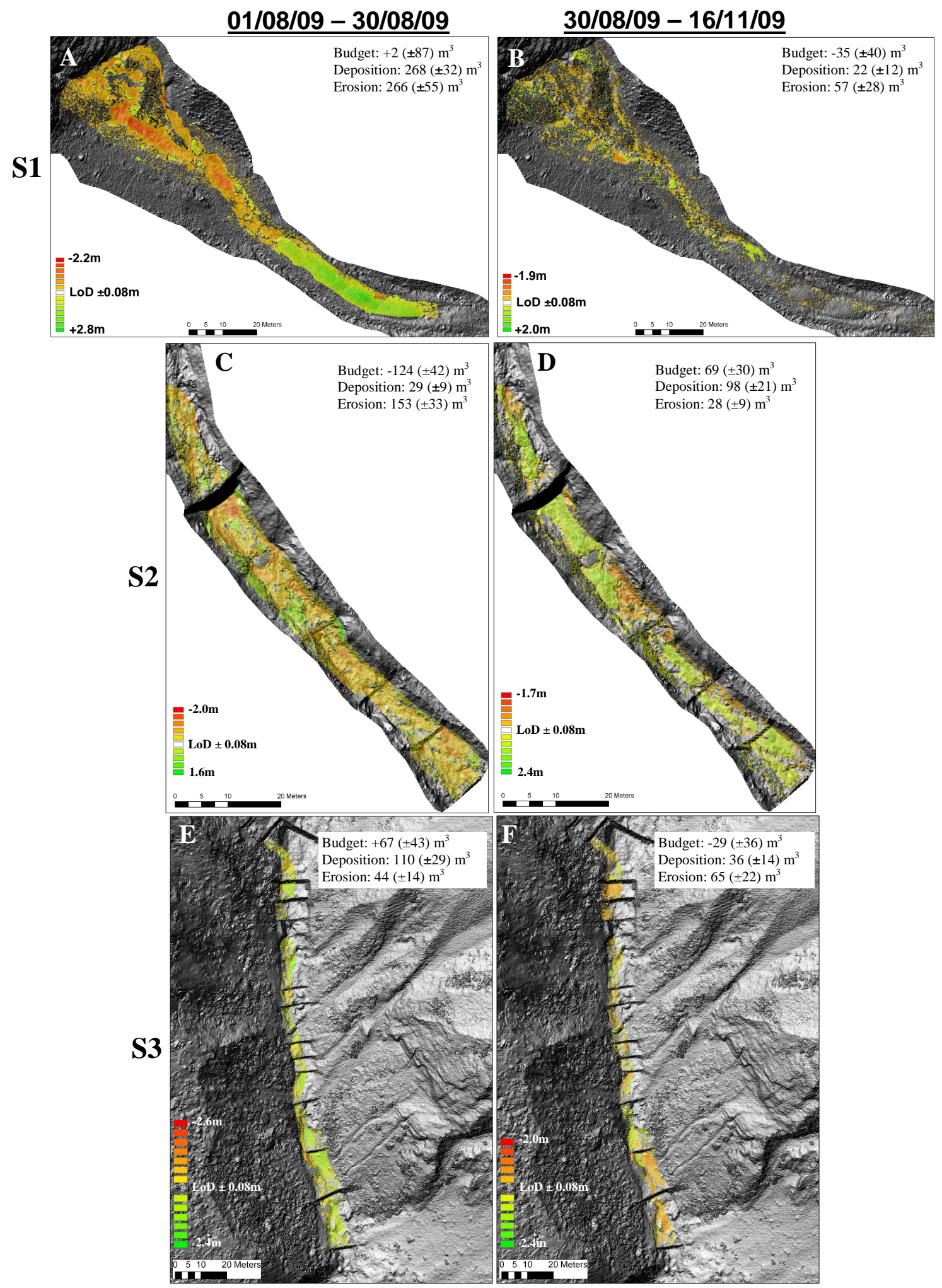

Fig. 9. DEM of differences derived from TLS resurveys of the S1 (A and B), S2 (C and D) and S3 (E and F) sites on the Manival between August and November 2009; LoD: level of detection of significant elevation changes based on the RMSE of the merging process. 


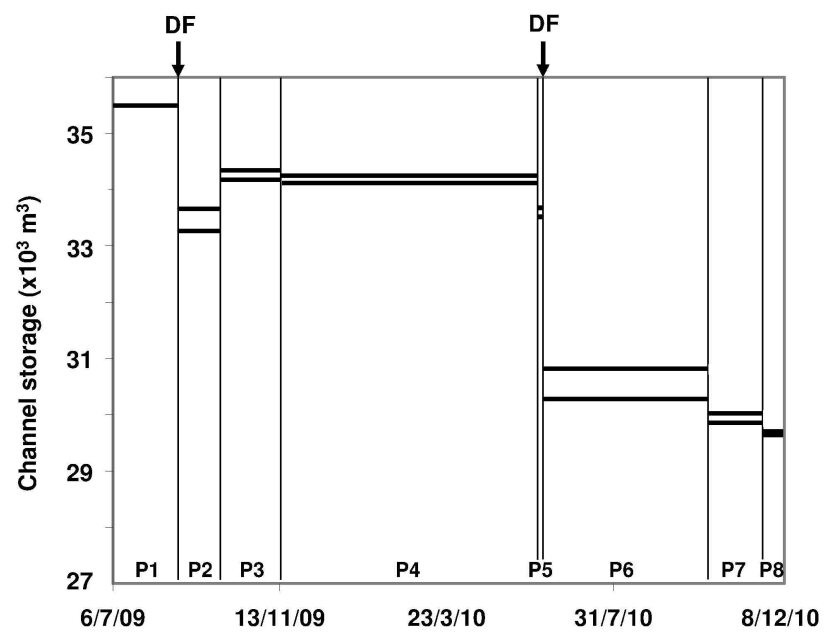

Fig. 10. Evolution of in-channel sediment storage during the monitoring period along the Manival study reach. Upper and lower limits are plotted according to the calculated uncertainty. DF denoted debris-flow occurrences.

\section{Discussion}

Gregoretti and Fontana (2008) found that debris-flows in the Dolomites (Italian Alps) formed due to the scouring effect of critical discharge from peak runoff. They also found that the triggering areas are located where sediment is available and where overland flow can occur. Observations in the Manival Torrent are consistent with these findings; channelized debris-flows were initiated in the proximal reach of the main channel where most sediment storage is present. Triggering occurred during high intensity rainfalls which produced the critical discharge. For the two debris-flow events, clear field observations upstream from the main channel showed that surface water runoff was initiated in the upper catchment producing water surges (indicated by high water marks). Morphological signatures of bedload transport were clearly detected in these upper reaches (sorted unconsolidated gravel deposits), without any signs of debris-flow propagation (unsorted levee, lobe, lag and terminal deposits with a fine sediment matrix). Multiple surges occur in the Manival where we do not know the exact timing of the headwater's sediment transport in relation to the main channel debris-flow. However, the sediment budgets indicate that there was little sediment transfer between the channel and the upper catchment for all the surges combined.

Sediment budget reconstitutions showed that debris-flow volumes at the downstream end of the study reach are equivalent to net erosion along the main channel (Table 4, Fig. 6). The direct contribution of hillslope erosion to debris-flow volume was insignificant, despite the occurrence of talus slope failures during storm events (Fig. 9). Sediment transfer along the stream network was characterised by important spatial discontinuities during summer storms. Sediment

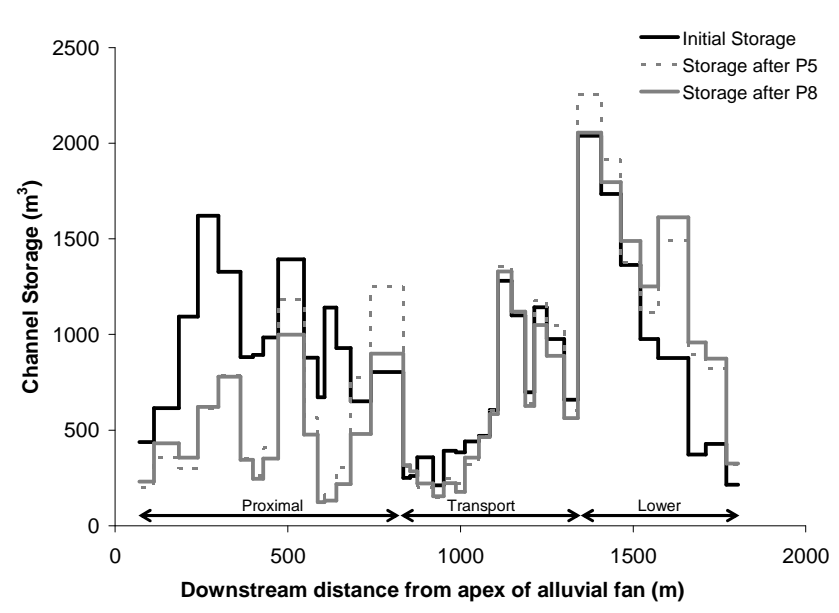

Fig. 11. The distribution of the channel storage change during the monitoring period derived from cross-section interpretation of the maximum debris-flow scouring surface. Within the monitoring period, the proximal reach had a large storage loss, the transport reach had little change and the lower reach gained in storage.

coming from talus slope failures or gully stores stayed captured in the distal reaches of headwaters and did not propagate down to the main channel (Fig. 9). A similar observation of sediment retention after a debris-flow in a second-order steep-slope channel was made at the Chalk Cliffs experimental site in Colorado (McCoy et al., 2010). These temporary storages were released during long duration and low intensity rainfall events in autumn and were deposited as gravel wedges along the main channel, partly refilling the previous debris-flow scoured channel. The retention of sediment in headwaters during the summer induced the formation of low sediment concentration water surges in the proximal main channel, with a high erosive "hydraulic load" (Rickenmann et al., 2003). When these sediment-laden water surges entered the main channel, they rapidly scoured the channel and transformed into debris-flows. The sediment concentration rapidly increased downstream, thereby reducing the erosive capacity of the flow.

The morphological responses to debris-flows along the main channel of the Manival torrent showed that debris-flow volumes increased by more than 3 orders of magnitude over streamwise distances of several hundreds of metres. Field observations reported for the Faucon Torrent in the French Alps revealed a similar increase of debris-flow volume by an incorporation of channel sediments, with scoured volumes of $\sim 10000 \mathrm{~m}^{3}$ along short reaches of $600 \mathrm{~m}$ (Remaitre et al., 2005). Sediment budget analysis of debris-flow events reported for the Illgraben in the Swiss Alps showed that the debris-flow volume at the exit of the catchment were one order of magnitude higher than typical landslide volumes observed in the production zone (Berger et al., 2011a). The normalization of scoured volumes by reach length for the Manival gave mean yield rates in the proximal reaches of 5 to 
$7 \mathrm{~m}^{3} \mathrm{~m}^{-1}$, with maximum values of $17 \mathrm{~m}^{3} \mathrm{~m}^{-1}$. These values are close to the $10 \mathrm{~m}^{3} \mathrm{~m}^{-1}$ reported in the Eastern Italian Alps (Marchi and D'Agostino, 2004) and within the range of 3.6 to $30 \mathrm{~m}^{3} \mathrm{~m}^{-1}$ from the recent compilation of yield rates for confined debris-flows (Hungr et al., 2005).

The respective influence of debris-flow and bedload transport on channel deformations during flow events is of crucial importance for the understanding of mountain stream morphodynamics. Field observations of morphological responses to these two types of flows in a same channel are not very common. The intensive topographic monitoring of the Manival Torrent gave a unique opportunity to characterise sediment budgets for both flow types. Even though it was easy to determine if a debris-flow occurs during each monitoring period and then to compare morphological responses of periods with and without debris-flows, it was much more difficult to discriminate the effects of the two flow types for the periods characterised by a debris-flow occurrence. In this latter case, channel deformations integrate the effects of both types since bedload transport is generally active during flow recession and between debris-flow surges. Our monitoring strategy was not designed to detect the variability of the flow properties during events and to cross-correlate with a high-frequency morphological signal. Without such information, it is not possible to unambiguously attribute scouring and filling phases to specific flow conditions. However, other field (Berger et al., 2011b) and experimental evidences (Mangeney et al., 2010) identify that the maximum scouring is related to the passage of the debris-flow front.

The influence of sediment recharge on debris-flows is quite evident in the Manival. Figures 10 and 11 show a large decrease in channel storage after the June 2010 debris-flow (P5). This affected the channel's response to rainfall for the rest of the year. In Fig. 12, rainfall burst intensity versus duration is plotted (bursts defined as a continuous rainfall, according to a 5-min time interval). These bursts are identified as to when the channel had storage (before June 2010 debrisflow), when the channel was without storage (after June 2010 debris-flow) and when a debris-flow occurred. The mean burst intensity and duration corresponds well with triggering thresholds from other monitoring sites (bursts defined with a 10-min time interval) (Badoux et al., 2008; Coe et al., 2008). However, when the channel was without storage, there were rainfall bursts similar to ones which triggered debris-flows. If storage was available, these bursts could have triggered debris-flows and, therefore, changing the threshold. This is clearly shown with the maximum burst intensities in Fig. 12. Unfortunately, there is not enough data for calculating the different triggering thresholds; however, a general range can still be observed (interpreted threshold range). The threshold range was approximately drawn to fit a line at the maximum extent for bursts with channel storage (lower-limit) and then a parallel line is drawn along the bursts which triggered debrisflows (upper-limit). This shows that the presence of storage controls the sensitivity of channel response to rainfall.
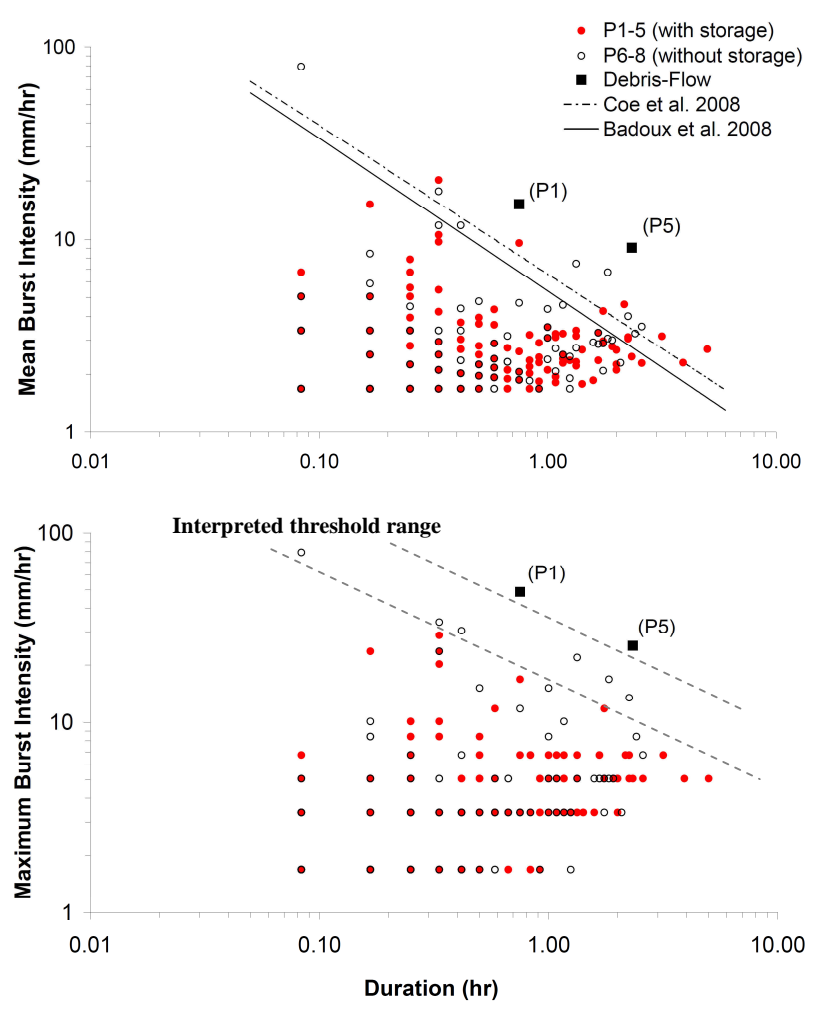

Fig. 12. Mean and maximum rainfall burst intensities against burst duration. Bursts are grouped according to available storage (before P6 debris-flow) (filled-red) and the channel with minimal storage (after P6 debris-flow) (empty-black). Debris-flows (solid-black) correspond well with thresholds from other sites with burst calculations; however, the presence of storage can influence the threshold line (interpreted threshold range).

The general patterns of spatial and temporal variability of geomorphic responses in the Manival catchment is consistent with other recent reported monitoring studies on sediment dynamic in debris-flow channels (Berger et al., 2011a; Fuller and Marden, 2010; Imaizumi et al., 2006; McCoy et al., 2010; Remaître et al., 2005). The pulses of sediment supply from hillslopes during the winter accumulated in first-order channels and are transferred to their next higher order reaches during spring and summer storms by debrisflows. These observations can be summarized by a conceptual model of seasonal cycles of sediment routing from low to high-order channels (Fig. 13). The model incorporates different event intensities:

1. Low rainfall intensity events during spring and summer (1-2 yr return period) remobilises sediment from first-order channels which have been recharged with debris during winter by slope processes (rockfall and snow avalanches). The debris may be entrained by slope failures generating short-travelling debris-flows, as observed by TLS survey of the S1 site during 


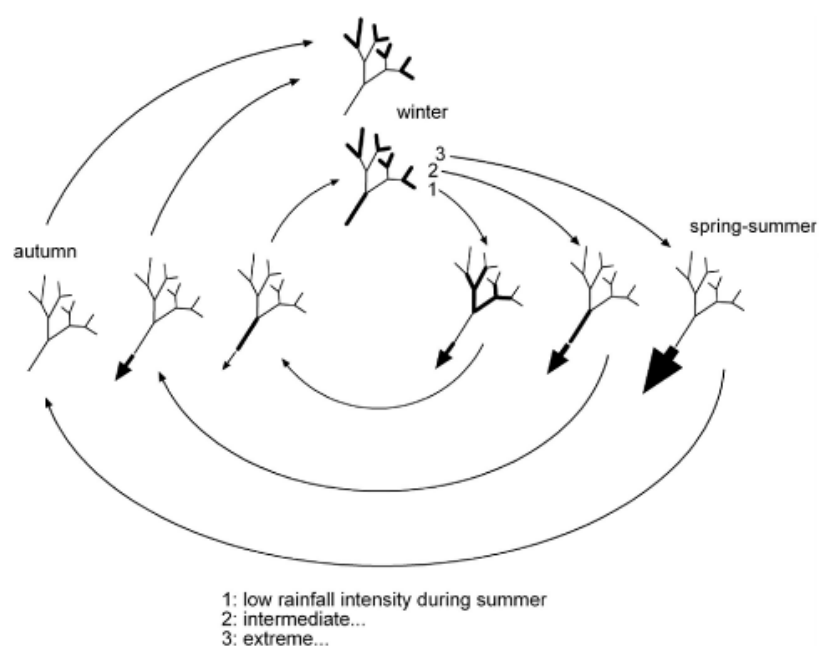

Fig. 13. Conceptual model of seasonal cycles of channel scour-andfill from first-order to high-order debris-flow channels according to level of storm intensity. Thickness of lines indicates the importance of storage. Seasonal cycles with low summer rainfall intensities have downstream progressing sediment waves initiated by pulses of sediment supply from hillslopes during winter. The cycle with intermediate summer storms has a summer flushing from the headwaters but large lag deposits continue to flush out in autumn. The extreme summer events have longer sediment routings which flush out most of the channels with minimal lag deposits during the summer storms.

summer 2009 (Fig. 9). We can also easily imagine that fine-grained debris may be mobilised as bedload by surface runoff and transported over short distances to second- or third-order channels. The net deposition observed for the third-order S3 site during summer 2009 is consistent with this scenario (Fig. 9e). Even if the expected general trend for intermediate channels is deposition of debris coming from headwaters, it is possible to observe local channel scouring (Fig. 9c). The stochastic nature of the sediment supply from hillslopes during winter can explain heterogeneous conditions of debris coverage in first-order channels and then variable conditions of sediment supply to intermediate channels during summer.

In high-order channels, the expected response during the summer is channel scouring by debris-flow entrainment of loose sediment accumulated during the preceding autumn. These debris-flows are formed by the sediment concentration increase of surface runoff when the flow starts to entrain sediment from the main channel. This has been consistently observed in the Manival during summer 2009 and 2010 (Fig. 6), where the volume of the two debris-flows obtained in the sediment trap was equivalent to net erosion along the main channel. During autumn, high-order channels are expected to receive sediment coming from debris in intermediate channels that accumulated during the summer. These sediment transfers are governed by bedload transport, with rainfall intensities being generally insufficient to initiate debris-flows. Net deposition in the main channel during autumn 2009 confirmed this scenario (Fig. 10). Qualitative observations made by the ONF-RTM38 after a small flow event in September 2008 (Peteuil et al., 2008) confirmed net deposition during autumn in the main channel of the Manival. It was not the case in autumn 2010, where net erosion was observed (Fig. 10). This may be attributed to a low sediment supply from hillslopes during winter, which may explain low sediment availability in intermediate channels.

2. Intermediate rainfall intensity in the summer was not observed during the monitoring periods. However, it can be assumed that the storage in the main channel is still evacuated out as a debris-flow. In the headwaters, longer travel distances would be observed with more continuity in the sediment routing. The headwater material could potentially contribute to the main channel debris-flow as well as depositing material in the main channel. In autumn, this new material would then continue to mobilize out of the channel in the form of gravel wedges.

3. Extreme rainfall intensity in the summer flushes sediment from first- to fourth-order channels out of the catchment system. An illustration of this is provided by the recent debris-flow history of the Manival. A large landslide occurred in the upper catchment during winter 1991, with a volume of $26000 \mathrm{~m}^{3}$ estimated from ALS data. The archives of ONF-RTM38 revealed that during the summer of 1991, two important debrisflows occurred and deposited a cumulative volume of $25000 \mathrm{~m}^{3}$ in the sediment trap. The large hillslope pulse depositing in the headwaters in the winter was essentially flushed out of the catchment during rainfall events in the summer.

\section{Conclusions}

This study revealed the importance of detailed catchmentscale field monitoring to understand debris-flow and bedload sediment transfer. Longer monitoring periods is needed for a more complete understanding of the proposed conceptual model. However, this study reveals important time shifts in scour-and-fill sequences in this active torrent catchment for common flow events. The two important processes, bedload (channel recharge) and debris-flow (channel scouring), are identified to be the seasonal forcings for sediment transfer in the torrent catchment. Finally, sediment pulses from hillslopes are the original control for these processes where further research is still needed. 
The conceptual model provides a better understanding on seasonal cycles of scour-and-fill. Some authors provide similar sediment routing schemes but at a much longer timescale (Benda, 1990). The presented model provides valuable input for assessing current and potential hazards (seasonal and extreme). The determination of where and when important storages occur allows for more effective management in these catchments.

Acknowledgements. This research was supported by InterregAlpine Space-PARAmount European project and the PGRN (Pôle Grenoblois d'étude et de recherche pour la prévention des Risques Naturels, Conseil Général de l'Isère). The ONF-RTM 38 is acknowledged for facilitating field access to the Manival. Bruno Bacq, Mathieu Cassel, Michael Deschatres, Adeline Heymann, Hugo Jantzi, Mathieu Labbé, Oldrich Navratil, Emilien Parisot, Sandrine Tacon and Nicolas Talaska are acknowledged for their assistance during the fieldwork. This paper also benefits from discussions with Christophe Peteuil (ONF-RTM 38). We also thank the reviewers and the editor for their thorough evaluations.

Edited by: A. Günther

Reviewed by: A. Remaitre and another anonymous referee

\section{References}

Ashmore, P. E. and Church, M. A.: Sediment transport and river morphology: A paradigm for study, in: Gravel-Bed Rivers in the Environment, edited by: Klingeman, P. C., Beschta, R. L., Komar, P. D., and Bradley, J. D., Water Resource Publications, LLC, Highlands Ranch, Colorado, 115-148, 1998.

Badoux, A., Graf, C., Ryhner, J., Kuntner, R., and McArdell, B. W.: A debris-flow alarm system for the Alpine Illgraben catchment: design and performance, Nat. Hazards, 49, 517-539, 2008.

Benda, L.: The influence of debris flows on channels and valley floors in the Oregon Coast Range, USA, Earth Surf. Proc. Land., 15, 457-466, 1990.

Benda, L. E. and Dunne, T.: Sediment routing by debris flow, International Association for Hydrological Sciences, 165, 457-466, 1987.

Berger, C., McArdell, B. W., and Schlunegger, F.: Sediment transfer patterns at the Illgraben catchment, Switzerland: Implications for the time scales of debris flow activities, Geomorphology, 125, 421-432, 2011a.

Berger, C., McArdell, B. W., and Schlunegger, F.: Direct measurement of channel erosion by debris flows, Illgraben, Switzerland, J. Geophys. Res., 116, F01002, doi:10.1029/2010JF001722, 2011b.

Besl, P. J. and McKay, N. D.: A method for registration of 3-D shapes, IEEE T. Pattern Anal., 14, 239-256, 1992.

Bovis, M. J. and Jakob, M.: The role of debris supply conditions in predicting debris flow activity, Earth Surf. Proc. Land., 24, 1039-1054, 1999.

Coe, J. A., Kinner, D. A., and Godt, J. W.: Initiation conditions for debris flows generated by runoff at Chalk Cliffs, central Colorado, Geomorphology, 96, 270-297, 2008.

Djerboua, A.: Prédétermination des pluies et crues extrêmes dans les Alpes franco-italiennes: prévision quantitative des pluies journalières par la méthode des analogues, $\mathrm{PhD}$ thesis, Institute National Polytechnique de Grenoble, Grenoble, 212 pp., 2001.

Djerboua, A. and Lang, M.: Comparaison de différents modes d'echantillonnage pour l'estimation du gradex des pluies, Revue des Sciences de l'Eau, 20, 111-125, 2007.

Ferguson, R. I. and Ashworth, P. J.: Spatial patterns of bedload transport and channel change in braided and near-braided rivers, in: Dynamics of Gravel-Bed Rivers, edited by: Billi, P., Hey, R. D., and Thorne, C. R., Wiley, Chichester, 477-496, 1992.

Fuller, I. C. and Marden, M.: Rapid channel response to variability in sediment supply: Cutting and filling of the Tarndale Fan, Waipaoa catchment, New Zealand, Mar. Geol., 270, 45-54, 2010.

Gregoretti, C. and Fontana, G. D.: The triggering of debris flow due to channel-bed failure in some alpine headwater basins of the Dolomites: analyses of critical runoff, Hydrol. Process., 22, 2248-2263, 2008.

Hungr, O., McDougall, S., and Bovis, M.: Entrainment of material by debris flows, in: Debris-Flow Hazards and Related Phenomena, edited by: Jakob, M. and Hungr, O., Springer, Berlin Heidelberg, Germany, 135-158, 2005.

Iavarone, A., Vagners, D.: Sensor fusion: Generating 3D by combining airborne and tripod mounted LIDAR data. In: Proceedings of the International Workshop on Visualization and Animation of Reality-Based 3D Models 2003, Engadin, Switzerland, International Archives of the Photogrammetry, Remote Sensing and Spatial Information Sciences, 34, 7 pp., 2003.

Imaizumi, F., Sidle, R. C., Tsuchiya, S., and Ohsaka, O.: Hydrogeomorphic processes in a steep debris flow initiation zone, Geophys. Res. Lett., 33, L10404, doi:10.1029/2006GL026250, 2006.

Jaboyedoff, M., Baillifard, F., Couture, R., Locat, J., and Locat, P. Toward preliminary hazard assessment using DEM topographic analysis and simple mechanic modeling, Landslides Evaluation and Stabilization, London, 191-197, 2004.

Jaboyedoff, M. and Derron, M. H.: A new method to estimate the infilling of alluvial sediment of glacial valleys using a sloping local base level, Geografia Fisica e Dinamica Quaternaria, 28, 37-46, 2005.

Jakob, M., Bovis, M., and Oden, M.: The significance of channel recharge rates for estimating debris-flow magnitude and frequency, Earth Surf. Proc. Land., 30, 755-766, 2005.

Lopez Saez, J., Corona, C., Stoffel, M., Gotteland, A., Berger, F., and Liébault, F.: Debris-flow activity in abandoned channels of the Manival torrent reconstructed with LiDAR and tree-ring data, Nat. Hazards Earth Syst. Sci., 11, 1247-1257, doi:10.5194/nhess-11-1247-2011, 2011.

Loye, A., Pedrazzini, A., Theule, J. I., Jaboyedoff, M., Liébault, F., and Metzger, R.: Influence of bedrock structures on the spatial pattern of erosional landforms in small alpine catchments, Earth Surf. Proc. Land., in press, 2012.

Mangeney, A., Roche, O., Hungr, O., Mangold, N., Faccanoni, G., and Lucas, A.: Erosion and mobility in granular collapse over sloping beds, J. Geophys. Res., 115, F03040, doi:10.1029/2009JF001462, 2010.

Marchi, L. and D'Agostino, V.: Estimation of debris-flow magnitude in the Eastern Italian Alps, Earth Surf. Proc. Land., 29 207-220, 2004.

Martin, Y. and Church, M.: Bed-material transport estimated from channel surveys: Vedder River, British Columbia, Earth Surf. 
Proc. Land., 25, 1011-1024, 1995.

McCoy, S. W., Kean, J. W., Coe, J. A., Staley, D. M., Wasklewicz, T. A., and Tucker, G. E.: Evolution of a natural debris flow: in situ measurements of flow dynamics, video imagery, and terrestrial laser scanning, Geology, 38, 735-738, 2010.

Otto, J.-C., Schrott, L., Jaboyedoff, M., and Dikau, R.: Quantifying sediment storage in a high alpine valley (Turtmanntal, Switzerland), Earth Surf. Proc. Land., 34, 1726-1742, 2009.

Peteuil, C., Maraval, C., Bertrand, C., and Monier, G.: Torrent du Manival: Schéma d'aménagement et de gestion du bassin versant contre les crues, Unpublished technical report; Office National des Forêts, Service de Restauration des Terrains en Montagne de l'Isère, Grenoble, France, 107 pp., 2008.

Rabatel, A., Deline, P., Jaillet, S., and Ravanel, L.: Rock falls in high-alpine rock walls quantified by terrestrial lidar measurements: A case study in the Mont Blanc area, Geophys. Res. Lett., 35, L10502, doi:10.1029/2008GL033424, 2008.

Raven, E. K., Lane, S. N., Ferguson, R. I., and Bracken, L. J.: The spatial and temporal patterns of aggradation in a temperate, upland, gravel-bed river, Earth Surf, Proc. Landf., 34, 1181-1197, 2009.
Reid, S. C., Lane, S. N., Berney, J. M., and Holden, J.: The timing and magnitude of coarse sediment transport events within an upland, temperate gravel-bed river, Geomorphology, 83, 152-182, 2007.

Remaître, A., Malet, J. P., and Maquaire, O.: Morphology and sedimentology of a complex debris flow in a clay-shale basin, Earth Surf. Proc. Land., 30, 339-348, 2005.

Rickenmann, D., Weber, D., and Stepanov, B.: Erosion by debris flows in field and laboratory experiments, Debris-Flow Hazards Mitigation: Mechanics, Prediction, and Assessment, 883-894, 2003.

Veyrat-Charvillon, S. and Memier, M.: Stereophotogrammetry of archive data and topographic approaches to debris-flow torrent measurements: Calculation of channel-sediment states and a partial sediment budget for Manival torrent (Isere, France), Earth Surf. Proc. Land., 31, 201-219, 2006. 